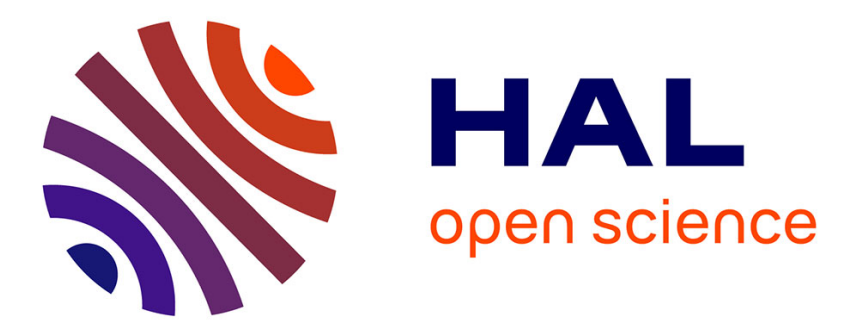

\title{
Diketopyrrolopyrrole-Porphyrin Conjugates as Broadly Absorbing Sensitizers for Dye-Sensitized Solar Cells
}

Julien Warnan, Ludovic Favereau, Frédéric Meslin, Marjorie Severac, Errol Blart, Yann Pellegrin, Denis Jacquemin, Fabrice Odobel

\section{To cite this version:}

Julien Warnan, Ludovic Favereau, Frédéric Meslin, Marjorie Severac, Errol Blart, et al.. Diketopyrrolopyrrole-Porphyrin Conjugates as Broadly Absorbing Sensitizers for Dye-Sensitized Solar Cells. ChemSusChem, 2012, 5 (8), pp.1568-1577. 10.1002/cssc.201100764 hal-03402670

\section{HAL Id: hal-03402670 \\ https://hal.science/hal-03402670}

Submitted on 25 Oct 2021

HAL is a multi-disciplinary open access archive for the deposit and dissemination of scientific research documents, whether they are published or not. The documents may come from teaching and research institutions in France or abroad, or from public or private research centers.
L'archive ouverte pluridisciplinaire $\mathbf{H A L}$, est destinée au dépôt et à la diffusion de documents scientifiques de niveau recherche, publiés ou non, émanant des établissements d'enseignement et de recherche français ou étrangers, des laboratoires publics ou privés. 


\title{
Diketopyrrolopyrrole-porphyrin conjugates as broadly absorbing sensitizers for dye-sensitized solar cells
}

Julien Warnan, Ludovic Favereau, Frédéric Meslin, Marjorie Severac, Errol Blart, Yann Pellegrin, Denis Jacquemin* and Fabrice Odobel*.

Université de Nantes, CNRS, Chimie et Interdisciplinarité: Synthèse, Analyse, Modélisation (CEISAM), UMR CNRS $n^{\circ}$ 6230, 2, rue de la Houssinière - BP 92208 - 44322 Nantes Cedex

3, France. Tel: +33 (0)2511254 29. Fax: +33 (0)2 51125402.

E-mail: Fabrice.Odobel@univ-nantes.fr.

\begin{abstract}
A series of four new push-pull zinc porphyrin-based dyes were synthesized for hybrid photovoltaic solar cells with a view of enhancing the light harvesting efficiency around 550 $\mathrm{nm}$ with a diketopyrrolopyrrole unit. The strength of the donor side of the push-pull porphyrin was tuned by affixing the electron rich 4,4'-dimethoxydiphenylamine group at the meso position of the macrocycle, and the influence of the distance between the semi-conductor surface and the porphyrin chromophore was assessed by introducing different $\pi$-conjugated spacers. Charge transfer transitions over great distances were characterized by electronic absorption spectroscopy and DFT calculations. The absorption and photoaction spectra of the new bichromophoric dyes spans the whole visible spectrum to the red, implying a better light harvesting efficiency than regular porphyrin, since DPP and porphyrin's absorption spectra complement one another. Photovoltaic conversion efficiencies accordingly increase from 2.40 to $5.19 \%$. Interestingly the best overall efficiency was reached with dye $\mathbf{3}$, lacking the powerful donating group in meso position of the porphyrin core. Optical and electrochemical measurements coupled to TD-DFT calculations give insight into the deleterious effect of the 4,4'-dimethoxydiphenylamine on the photovoltaic performances, paving the way towards the design of efficient push-pull porphyrin-based sensitizers.
\end{abstract}

\section{Keywords:}

diketopyrrolopyrrole $\cdot$ nanoparticles $\cdot$ porphyrin· semiconductor $\cdot$ sensitizer $\cdot$ solar cell 


\section{Introduction}

Nanocrystalline dye-sensitized solar cells (DSSCs) represent promising low cost alternatives to conventional inorganic photovoltaic cells. ${ }^{1}$ During the last decade, there has been an increasing interest in the development of ruthenium-free sensitizers for DSSC. ${ }^{2}$ However, the organic sensitizers approaching the performances of the best ruthenium complexes are still rare $^{3-6}$ Porphyrin derivatives are the archetypal light collector of photosynthetic organisms and they are naturally becoming the main focus of several synthetic groups designing new organic sensitizers for DSSCs. Indeed, there have been recently many studies in this context. ${ }^{5-}$ 7 More specifically, Diau and co-workers recently developed very efficient push-pull porphyrin dyes which are the best performing sensitizers reported so far. ${ }^{4-6}$ However, it is observed that porphyrins exhibit a weak absorbance around $550 \mathrm{~nm}$, between the Soret and the Q-bands, which limits the photocurrent density in a region of intense solar flux. Therefore, it is unsurprising that record efficiencies of $11 \%^{4}$ and $12.3 \%^{6}$ were achieved by cosensitization when a porphyrin is associated to a push-pull dye whose maximum absorption was specifically positioned at $550 \mathrm{~nm}$. The golden design principle of organic dyes is the construction of push-pull systems, which intrinsically exhibit charge transfer absorption bands in the visible region and facilitate charge injection. On the other hand, diketopyrrolopyrrole (DPP) is a well-known chromogen but it surprisingly received little attention so far as a building block for the development of organic sensitizers in DSSCs. ${ }^{8}$ However, DPPs could be targets of choice as they possess several qualities: very good photostability, direct synthetic accessibility and a hallmark intense absorption band around $550 \mathrm{~nm}$, where porphyrins weakly absorb. Therefore, DPP present well-suited properties to be incorporated as complementary chromogen along with a porphyrin sensitizer; an association which has never been reported previously, even in the framework of other applications. 


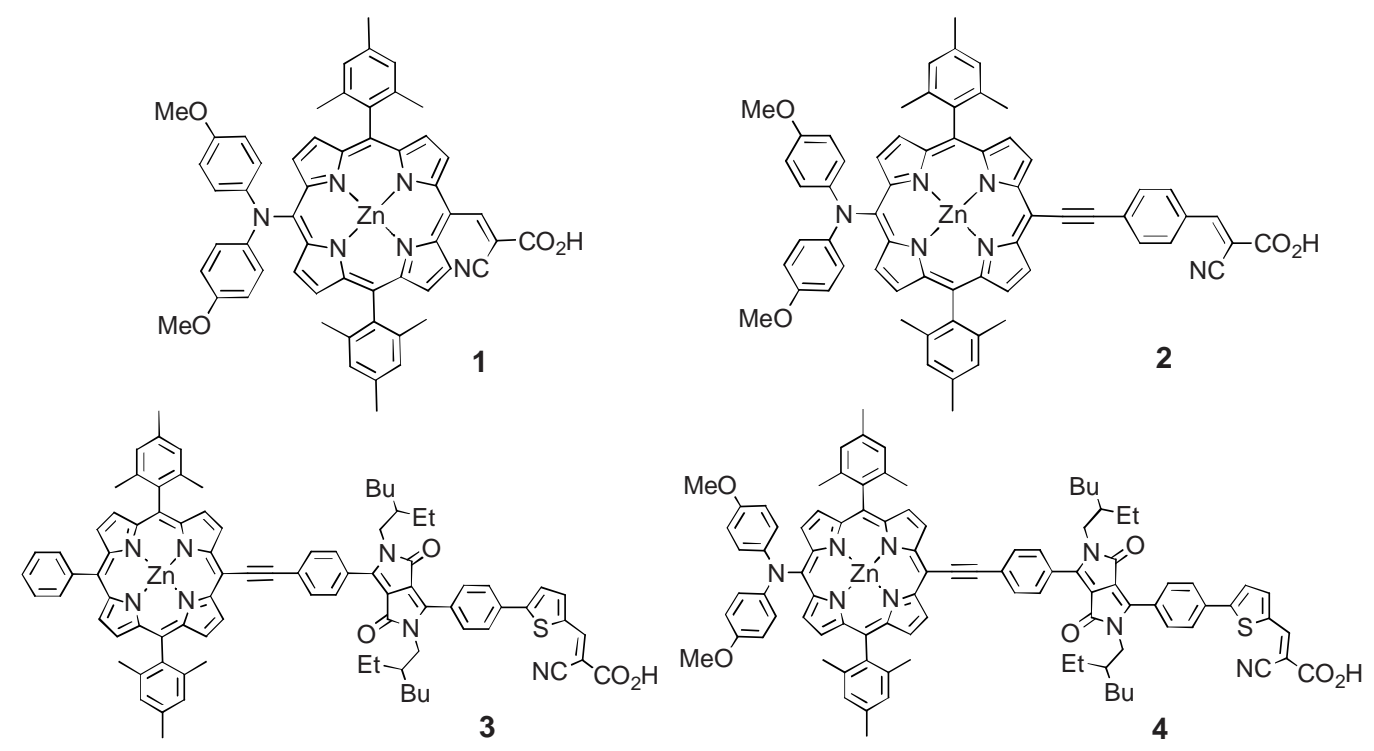

Chart 1. Structures of the porphyrin sensitizers investigated herein.

This idea was at the origin of the development of the bichromophoric dyes $\mathbf{3}$ and $\mathbf{4}$ shown in Chart 1. Two additional dyes, $\mathbf{1}$ and $\mathbf{2}$, were also prepared to investigate the structureproperties relationship, to assess the role of the DPP moiety and to draw molecular design rules. These four new porphyrin dyes are all composed of a zinc porphyrin and contain the same cyanoacrylic acid anchoring group, but they differ by the nature of the spacer between the porphyrin and the anchor, the former being a direct bond (in 1), a phenylethynyl spacer (in 2), or a DPP unit (in 3 and 4). On the other hand, the two diketopyrrolopyrrole/porphyrin conjugates only differ by the meso substituent at the extremity of the system, $\boldsymbol{3}$ bearing a simple phenyl while the other porphyrins are capped with a dianisylamine group. The synthesis and the photovoltaic investigations of these series of four new sensitizers demonstrate the great potential of diketopyrrolopyrrole/porphyrin mix and provide some guidelines for the design of new porphyrin based sensitizers.

\section{Synthesis of the sensitizers}

The synthesis of Trans- $\mathrm{A}_{2} \mathrm{~B}_{2}$-porphyrin is well described in literature since it represents the basic framework for push-pull molecules used for several applications. ${ }^{9}$ The initial halogenation of one of the electron-rich meso-positions furnishes an open gate to versatile functionalization. ${ }^{10}$ Indeed, the syntheses of all four dyes 1-4 start with the 5-bromo-10,20dimesityl porphyrin (5) which was engaged in different palladium coupling reactions depending on the targeted product. The bromoporphyrin 5 was engaged in a Buchwald- 
Hartwig cross-coupling with the electron-rich dianisylamine in presence of palladium(II) acetate, dry caesium carbonate and DPEphos to afford the aminoporphyrin 6 with a good yield of $85 \%$ (Scheme 1). ${ }^{11}$ An aldehyde group was then introduced on the remaining electron rich meso-position via a Vielsmeier-Hack reaction performed on the copper(II) porphyrin. ${ }^{12}$ Copper was then removed in strong acidic conditions to give porphyrin 7 in $70 \%$ yield. The latter was then reacted with the cyanoacetic acid in a Knoevenagel reaction, followed by zinc(II) insertion into the macrocyclic cavity to eventually achieve the synthesis of dye $\mathbf{1}$.
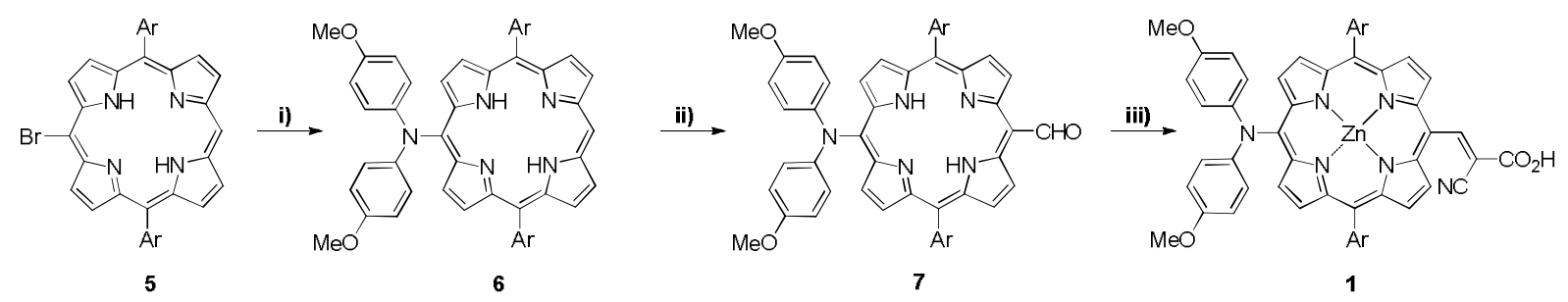

Scheme 1. Synthesis of dye 1. Reagents and conditions : i) Dianisylamine, $\mathrm{Pd}(\mathrm{OAc})_{2}, \mathrm{Cs}_{2} \mathrm{CO}_{3}, \mathrm{DPEphos}, \mathrm{THF}$, $85 \%$; ii) 1) $\mathrm{Cu}(\mathrm{OAc})_{2} .2 \mathrm{H}_{2} \mathrm{O}, \mathrm{CH}_{3} \mathrm{OH}: \mathrm{CH}_{2} \mathrm{Cl}_{2}, 100 \%$; 2) DMF, $\mathrm{POCl}_{3}, \mathrm{CH}_{2} \mathrm{Cl}_{2}, 80 \%$; 3) $\mathrm{H}_{2} \mathrm{SO}_{4}, \mathrm{CH}_{2} \mathrm{Cl}_{2}, 87 \%$; iii) 1) cyanoacetic acid, piperidine, $\left.\mathrm{CH}_{3} \mathrm{CN}, 62 \% ; 2\right) \mathrm{Zn}(\mathrm{OAc})_{2} \cdot 2 \mathrm{H}_{2} \mathrm{O} \mathrm{CH} \mathrm{CH}_{3} \mathrm{OH}: \mathrm{CH}_{2} \mathrm{Cl}_{2}, 100 \%$

The synthesis of sensitizer 2 starts with the halogenation of porphyrin $\mathbf{6}$ according to an electrophilic addition of bromide on meso-position and leads to compound $\mathbf{8}$ (Scheme 2). To avoid any copper coordination by the porphyrin macrocycle during the next step (Sonogashira coupling), the latter was first metallated by zinc acetate. The addition of the 4ethynylbenzaldehyde moiety was performed using palladium chemistry with Sonogashira's classical conditions for porphyrins, ${ }^{13}$ yielding product $\mathbf{9}$. This reaction furnished only $13 \%$ yield after $15 \mathrm{~h}$ and the starting material was principally recovered during the purification step. This poor conversion is certainly due to the sluggish oxidative addition of palladium in the first step of the catalytic cycle owing to the electron-rich dianisylamine which significantly increases electron density on meso-position. Despite this low yield the synthesis of dye $\mathbf{2}$ was achieved by a Knoevenagel condensation using cyanoacetic acid and piperidine. 

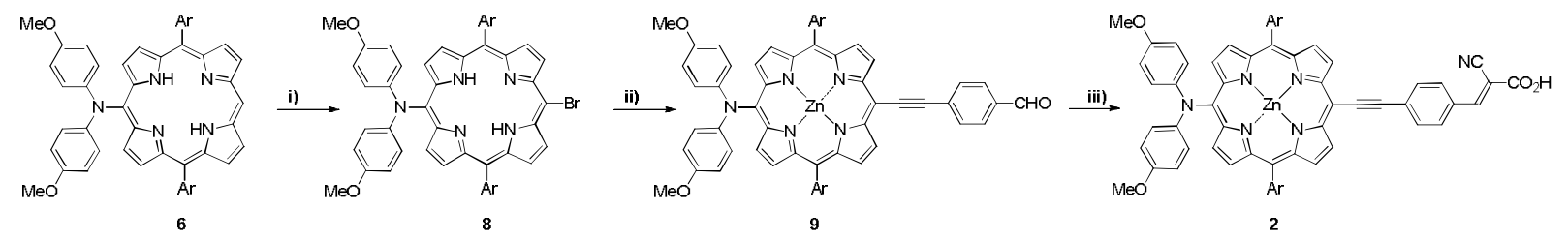

Scheme 2. Synthesis of dye 2. Reagents and conditions : i) $\mathrm{NBS}, \mathrm{CH}_{2} \mathrm{Cl}_{2}, 97 \%$; ii) 1 ) $\mathrm{Zn}(\mathrm{OAc})_{2} .2 \mathrm{H}_{2} \mathrm{O}$, $\mathrm{CH}_{3} \mathrm{OH}: \mathrm{CH}_{2} \mathrm{Cl}_{2}, 100 \%$; 2) 4-ethynylbenzaldehyde, $\mathrm{Pd}_{2}(\mathrm{dba})_{3}, \mathrm{PPh}_{3}, \mathrm{CuI}, \mathrm{Et}_{3} \mathrm{~N}, \mathrm{THF}, 13 \%$; iii) cyanoacetic acid, piperidine, $\mathrm{CH}_{3} \mathrm{CN}, 31 \%$

The two bichromophoric sensitizers $\mathbf{3}$ and $\mathbf{4}$ were prepared using a convergent strategy. The porphyrin part of dye $\mathbf{3}$ was obtained in one step via a Suzuki-Miyaura cross-coupling between porphyrin 5 and the phenylboronic acid (Scheme 3). The reaction furnished the trisarylporphyrin which was immediately halogenated in presence of $N$-bromosuccinimide. This double reaction permitted an easier purification of the bromoporphyrin $\mathbf{1 0}$ without hardly affecting the overall yield (around 73\%). The additional DPP subunit, featuring a terminal alkyne and the anchoring group (compound 15), was synthesised according to a previously described route and was subsequently alkylated with 2-ethylbromohexane to enhance its solubility in organic solvents yielding compound $\mathbf{1 1}$ (Scheme 4). ${ }^{14}$ A Suzuki-Miyaura reaction was then performed with one equivalent of the 4-formylthiophenylboronic acid to yield the DPP derivative 12. Statistical conditions afforded molecule 12 in $34 \%$ yield as well as the starting material and the bis-coupled product. A Sonogashira cross-coupling with ethynyltrimethylsilane followed by tetrabutylammonium fluoride (TBAF) deprotection furnished the terminal alkyne $\mathbf{1 4}$ with good yields. Initially, we considered the introduction of the anchoring group after the chromophores coupling reaction to limit the number of difficult purification steps on acidic compounds; unfortunately we did not succeed in performing any Knoevenagel reaction on the porphyrin-DPP-aldehyde adduct. Consequently, we chose to introduce the carboxylic anchor earlier in the synthesis, on the DPP derivative 14, which led to 15 with $50 \%$ yield (Scheme 3). 

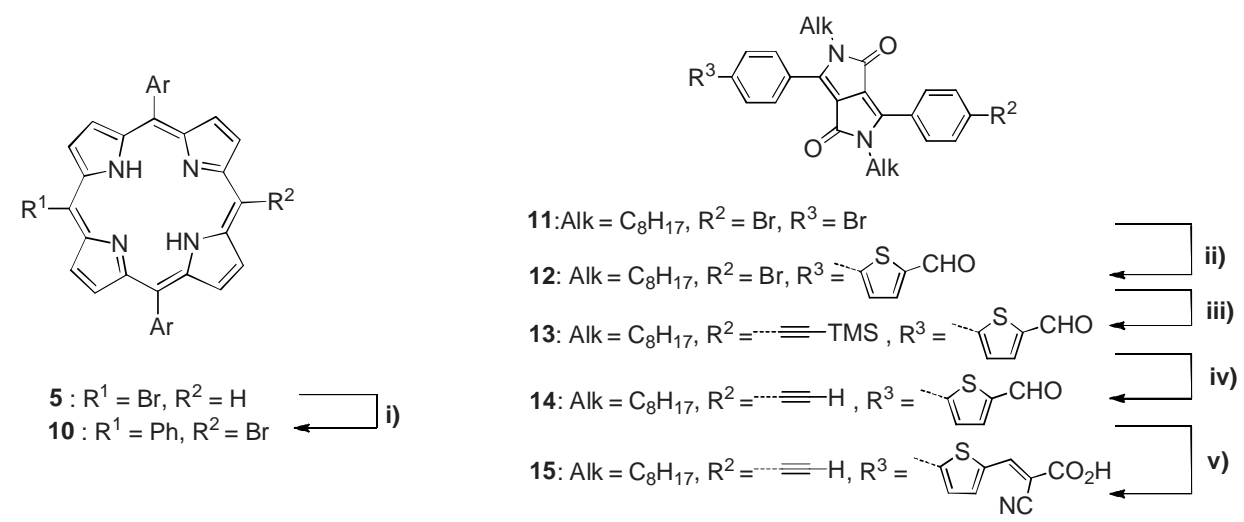

Scheme 3. Synthesis of precursors of dye 3. Reagents and conditions : i) 1) phenylboronic acid, $\left.\mathrm{Pd}\left(\mathrm{PPh}_{3}\right)_{4}, \mathrm{~K}_{3} \mathrm{PO}_{4}, \mathrm{THF} ; 2\right) \mathrm{NBS}$, pyridine, $\mathrm{CHCl}_{3}, 73 \%$; ii) 4-formylthiophenylboronic acid, $\mathrm{Pd}\left(\mathrm{PPh}_{3}\right)_{4}, \mathrm{Na}_{2} \mathrm{CO}_{3}$, THF: $\mathrm{H}_{2} \mathrm{O}, 34 \%$; iii) ethynyltrimetylsilane, $\mathrm{Pd}\left(\mathrm{PPh}_{3}\right)_{4}, \mathrm{CuI}, \mathrm{Et}_{3} \mathrm{~N}$, toluene, 97\%; iv) TBAF, THF, 95\%; v) cyanoacetic acid, piperidine, $\mathrm{CH}_{3} \mathrm{CN}: \mathrm{CHCl}_{3}$, reflux, $50 \%$;

Finally, the porphyrin $\mathbf{1 0}$ and the DPP unit $\mathbf{1 5}$ were linked together via a copper-free Heck type alkynylation reaction (Scheme 4). ${ }^{13}$ Zinc(II) was ultimately introduced in $\mathbf{1 6}$ to yield dye 3.

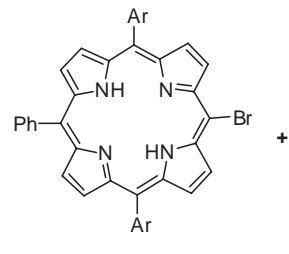

10

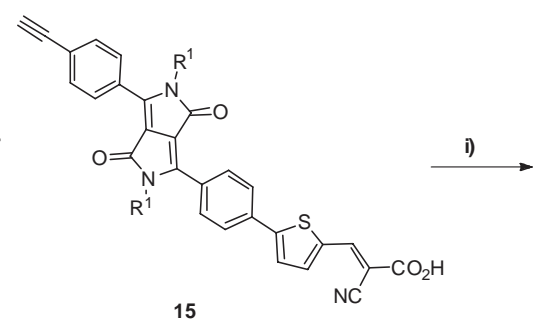

15

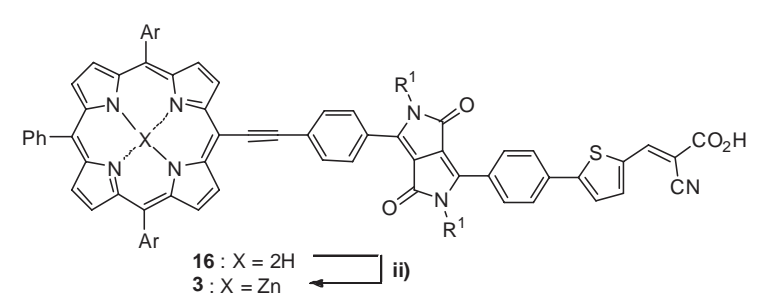

Scheme 4. Synthesis of dye 3. Reagents and conditions : i) $\mathrm{Pd}_{2}(\mathrm{dba})_{3}, \mathrm{AsPh}_{3}, \mathrm{Et}_{3} \mathrm{~N}, \mathrm{THF}: \mathrm{MeOH}, 38 \%$; ii) $\mathrm{Zn}(\mathrm{OAc})_{2}, \mathrm{CH}_{2} \mathrm{Cl}_{2}: \mathrm{MeOH}, 98 \%$

The synthesis of the push-pull porphyrin $\mathbf{4}$ was inspired from previously published routes. ${ }^{15,16}$ A protected alkyne was first introduced on the porphyrin core of molecule $\mathbf{5}$, followed by an iodination with diiodine in presence of hypervalent iodine (Scheme 6). The dianysilamine was subsequently introduced from a Buchwald-Hartwig coupling reaction with a satisfying 57\% yield. The advantage of this higher yield synthetic pathway, compared to the route used for $\mathbf{2}$, stems from the fact that the palladium cross-coupling reaction was run earlier, avoiding the sluggish oxidative addition generally encountered with electron rich substrates. As in the case of $\mathbf{3}$, the freshly deprotected porphyrin $\mathbf{1 9}$ moiety was linked to the bromo susbtituted DPP $\mathbf{1 2}$ 
via a Heck type alkynylation reaction. The synthesis of dye $\mathbf{4}$ was ended with the condensation of cyanoacetic acid and the zinc(II) metallation of the porphyrin.

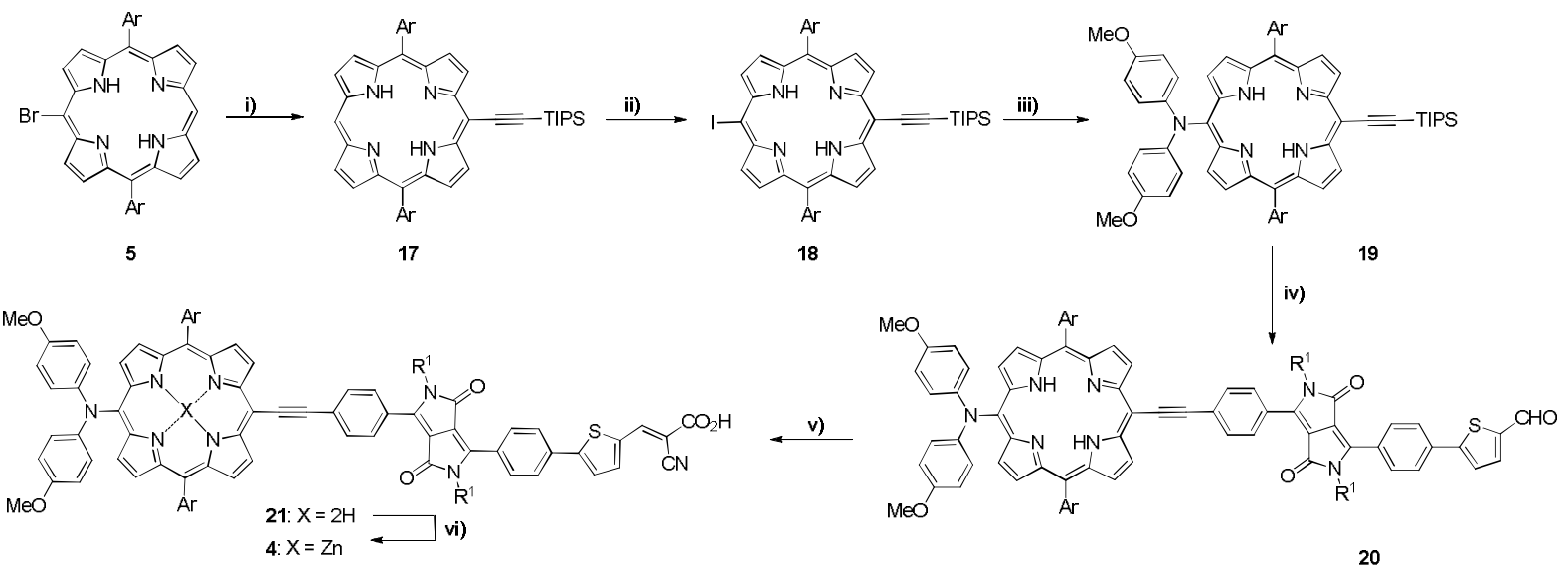

Scheme 5. Synthesis of dye 4. Reagents and conditions : i) 1) $\left.\mathrm{Zn}(\mathrm{OAc})_{2} \cdot 2 \mathrm{H}_{2} \mathrm{O}, \mathrm{CH}_{2} \mathrm{Cl}_{2}: \mathrm{MeOH} ; 2\right)$ ethynyltriisopropylsilane, $\mathrm{Pd}\left(\mathrm{PPh}_{3}\right)_{4}, \mathrm{CuI}, \mathrm{Et}{ }_{3} \mathrm{~N}$, THF; 3) $\mathrm{HCl}(2 \mathrm{~N}), 93 \%$; ii) $\mathrm{I}_{2}, \mathrm{PhI}\left(\mathrm{CF}_{3} \mathrm{CO}_{2}\right)_{2}$, pyridine, $\mathrm{CH}_{2} \mathrm{Cl}_{2}$, $80 \%$; iii) dianysylamine, $\mathrm{Pd}(\mathrm{OAc})_{2}$, DPEPhos, $\mathrm{Cs}_{2} \mathrm{CO}_{3}, \mathrm{THF}, 57 \%$; iv) 1) TBAF, THF, 2) 12, $\mathrm{Pd}_{2}(\mathrm{dba})_{3}, \mathrm{AsPh}_{3}$, $\mathrm{Et}_{3} \mathrm{~N}$, THF, $19 \%$; v) cyanoacetic acid, piperidine, THF, $20 \%$; vi) $\mathrm{Zn}(\mathrm{OAc})_{2} \cdot 2 \mathrm{H}_{2} \mathrm{O}, \mathrm{CH}_{2} \mathrm{Cl}_{2}: \mathrm{MeOH}, 95 \%$

\section{Electronic absorption spectra in solution and on $\mathrm{TiO}_{2}$ electrode}

The absorption spectra of the sensitizers, recorded in dichloromethane solution and on $\mathrm{TiO}_{2}$ electrodes, are respectively shown in Figures 2 and 3. The absorption spectra of the four sensitizers exhibit the classical intense Soret absorption band around $420 \mathrm{~nm}$ and the Q-bands around $650 \mathrm{~nm}$, which contain a significant charge transfer character corresponding to a charge shift from the porphyrin moiety towards the anchoring group (see quantum mechanical calculations below). However, the replacement of the dianisylamine group by a phenyl (from 4 to 3) induces a blue-shift and a decrease of the intensity of this Q-band, owing to a larger delocalization of the HOMO levels (Figures 2 and 3 and calculations below). The presence of the DPP unit reinforces the absorbance around $500 \mathrm{~nm}$ and this is particularly perceptible on the absorption spectra of $\mathbf{3}$ on $\mathrm{TiO}_{2}$ which exhibits a broad absorption band with a continuous plateau from 380-680 nm (Figure 3). For the photovoltaic measurements these dyes were chemisorbed on $\mathrm{TiO}_{2}$ films in presence and in absence of a co-adsorbate (chenodeoxycholic acid, CDCA) to limit their propensity to aggregate. From Figure 3, we can observe that CDCA does not significantly modify the absorption spectra since the shape and the full width at half maximum of the bands are rather constant upon CDCA co-adsorption. This indicates a 
modest degree of aggregation of these dyes upon chemisorption on $\mathrm{TiO}_{2}$, probably thanks to the long alkyl chains on the DPP unit and the mesityl groups on the meso positions of the porphyrins, which prevent close packing of the dyes. This is also consistent with the only slight (if any) improvement of the photovoltaic performances of the dyes in presence of CDCA.

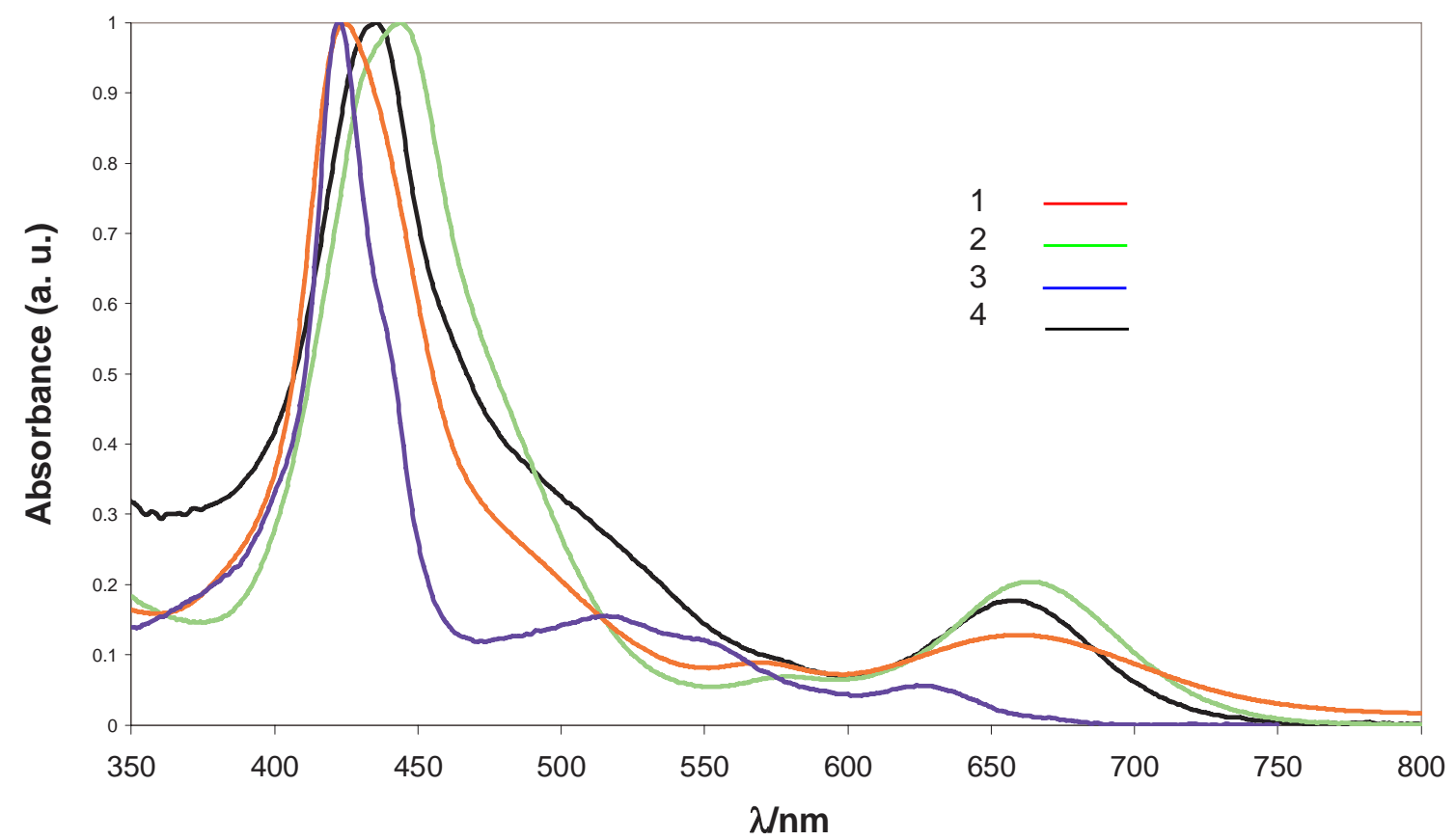

Figure 2. Normalized absorption spectra of the porphyrins 1-4 recorded in dichloromethane

Except porphyrin 3, the other porphyrins studied herein are not luminescent, therefore the zero-zero excitation energy was calculated from the wavelength at the edge of the lowest energy Q-band (Table 1). This indicates that the dianisylamine probably decreases the luminescence emission quantum yield, because of the stronger charge transfer character of the lowest excited-state. This is in agreement with other push-pull porphyrins published recently. ${ }^{16}$ 


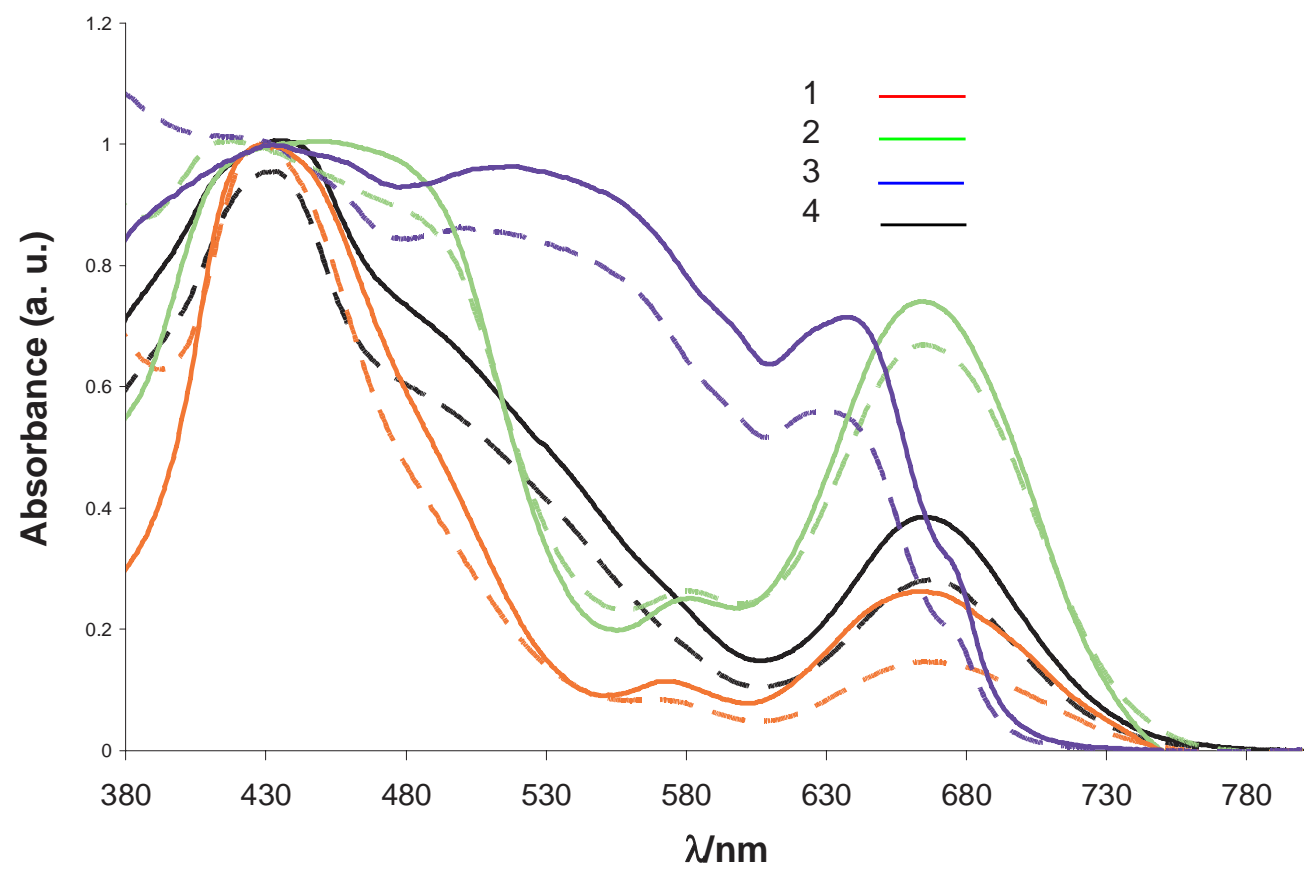

Figure 3. Normalized absorption spectra of the porphyrin sensitizers immobilized on $\mathrm{TiO}_{2}$ electrodes with chenodeoxycholic acid (dashed line) and without (straight line)

Table 1. Absorption and emission characteristics, redox potentials and injection Gibbs free energies of 1, 2, 3 and 4. SCE = Saturated Calomel Electrode. ${ }^{\mathrm{a}}$ Estimated from the wavelength at the tail of the lowest energy Q-band. ${ }^{\mathrm{b}}$ Calculated with the wavelength at the intersection $\left(\lambda_{\text {inter }}\right)$ of normalized absorption and emission spectra with the equation $\mathrm{E}_{00}=1240 / \lambda_{\text {inter }}{ }^{\mathrm{c}}$ Calculated according to the equation: $\mathrm{E}_{\mathrm{Ox}}\left(\mathrm{S}^{+} / \mathrm{S}^{*}\right)=\mathrm{E}_{\mathrm{Ox}}\left(\mathrm{S}^{+} / \mathrm{S}\right)-\mathrm{E}_{00}$. ${ }^{\mathrm{d}}$ Calculated according to the equation: $\Delta \mathrm{G}_{\mathrm{inj}}=0.74+\mathrm{E}_{\mathrm{Ox}}\left(\mathrm{S}^{+} / \mathrm{S}^{*}\right)$. ${ }^{\mathrm{e}}$ Calculated according to the equation: $\Delta \mathrm{G}_{\mathrm{reg}}=0.18-\mathrm{E}_{\mathrm{Ox}}\left(\mathrm{S}^{+} / \mathrm{S}\right)$.

\begin{tabular}{|c|c|c|c|c|c|c|}
\hline Dye & $\begin{array}{c}\mathrm{E}_{\text {Ox }}\left(\mathrm{S}^{+} / \mathrm{S}\right) \\
\mathrm{V} v s \mathrm{SCE}\end{array}$ & $\lambda_{\text {abs }} / \mathrm{nm}$ & $\begin{array}{c}\mathrm{E}_{00}\left(\mathrm{~S}^{*}\right) \\
\mathrm{eV}\end{array}$ & $\begin{array}{c}{ }^{\mathrm{C}} \mathrm{E}_{\mathrm{Ox}}\left(\mathrm{S}^{+} / \mathrm{S}^{*}\right) \\
\mathrm{V} v s \mathrm{SCE}\end{array}$ & $\begin{array}{c}{ }^{\mathrm{d}} \Delta \mathrm{G}_{\text {inj }} \\
(\mathrm{eV})\end{array}$ & $\begin{array}{c}{ }^{\mathrm{e}} \Delta \mathrm{G}_{\text {reg }} \\
(\mathrm{eV})\end{array}$ \\
\hline $\mathbf{1}$ & 0.51 & $424 ; 568 ; 656$ & $1.63^{\mathrm{a}}$ & -1.12 & -0.38 & -0.33 \\
\hline $\mathbf{2}$ & 0.54 & $439 ; 574 ; 668$ & $1.70^{\mathrm{a}}$ & -1.16 & -0.42 & -0.36 \\
\hline $\mathbf{3}$ & 0.80 & $422 ; 520 ; 625$ & $1.90^{\mathrm{b}}$ & -1.10 & -0.36 & -0.62 \\
\hline $\mathbf{4}$ & 0.50 & $427 ; 654$ & $1.67^{\mathrm{a}}$ & -1.17 & -0.43 & -0.32 \\
\hline
\end{tabular}




\section{Electrochemical properties}

The oxidation potentials of the dyes were determined by differential pulse voltammetry recorded on the $\mathrm{TiO}_{2}$ electrodes to assess the thermodynamic feasibility of the different electron transfer processes. Using the zero-zero energy of the singlet excited state $\left(\mathrm{E}_{00}\right)$ and the well-accepted values of the conduction band of $\mathrm{TiO}_{2}(-0.74 \mathrm{~V} \text { vs SCE})^{17}$ and that of the redox couple $\mathrm{I}_{3}{ }^{-} / \mathrm{I}^{-}(0.18 \mathrm{~V} \text { vs SCE})^{18}$ the electron injection Gibbs free energy $\left(\Delta \mathrm{G}_{\text {inj }}\right)$ and the dye regeneration Gibbs free energy $\left(\Delta \mathrm{G}_{\mathrm{reg}}\right)$ have been calculated (Table 1). The first oxidation process corresponds to an electron removal from the zinc porphyrin with a significant contribution of the dianisylamino substituent (see DFT calculation section) since they represent the most electron rich fragments of the molecule for the dyes $\mathbf{1 , 2}$ and $\mathbf{4}$. This is consistent with the lower oxidation of this type of porphyrin relative to that of a regular DPP unit and also in agreement with the quantum chemical calculations which show that the HOMO level is distributed on zinc porphyrin with a strong contribution on the amino group when it is present. In these systems, the diarylamino group contains methoxy substituents which significantly increase the electron donating ability and therefore, cathodically shift the redox potential in comparison to similar porphyrins reported by Diau and co-workers containing alkyl groups instead $\left(\mathrm{E}_{\mathrm{Ox}} \approx 0.7 \mathrm{~V} v \mathrm{SCE}\right) .{ }^{16}$ Conversely, the first oxidation potential of $\mathbf{3}$, lacking the diarylamino substituent, is anodically shifted compared to $\mathbf{1 , 2}$ and 4 in agreement with the neutral electronic effect of the phenyl. The calculated Gibbs free energies indicate that the electron injection and the dye regeneration reactions are both thermodynamically allowed processes for all the new porphyrins studied here. However, porphyrin 3 differs from the others because it is the single sensitizer for which the regeneration reaction is significantly exergonic $(\Delta \mathrm{G}=-0.62 \mathrm{eV})$, while the other dyes exhibit relatively weak driving forces $\left(\Delta \mathrm{G}_{\text {reg }} \approx-0.3 \mathrm{eV}\right)$ for a bimolecular reaction and multielectronic process known for its high overpotential. ${ }^{19,20}$

\section{Quantum mechanical calculations}

Time-Dependent Density Functional Theory (TD-DFT) calculations have been performed for the four dyes (see experimental section for details), in order to probe the nature of the electronic transitions implied in the different absorption bands. The main results are collated in Table 2 and Figure 4 which displays the structure and the frontier orbitals. The optimized structure of the four compounds present the expected trends: the core is almost flat, but the DPP moiety forms a dihedral angle of $c a .30^{\circ}$ with its side phenyl rings, while the electron 
rich dianisylamine group is arranged in a propeller-helix form. Nevertheless, the absence of spacer between the porphyrin and the anchoring group in $\mathbf{1}$ induces a twisting of $42^{\circ}$ between these two moieties. The dipole moments computed are relatively uniform for all structures: 89 D. The theoretical wavelengths listed in Table 2 are in reasonable agreement with experiment (see above): i) the Q-band is located around $650 \mathrm{~nm}$ for all systems, but 1 (608 $\mathrm{nm}$ ) and is also less intense for this latter dye; ii) introduction of a DPP unit implies the emergence of an extra band at ca. $510 \mathrm{~nm}$ (but its relative intensity seems to be overestimated by TD-DFT); iii) the most intense Soret transitions appear around $400 \mathrm{~nm}$ and one notes that 2 presents the most red-shifted Soret peak, which fits Figure 2. From Figure 4, it turns out that the HOMO is centred on the porphyrin and the electron rich arylamine group, whereas the LUMO is either a mix of the porphyrin and cyanoacrylic groups (1 and $\mathbf{2}$ ) or located on both the DPP and the anchoring group (3 and 4). To quantify the associated charge transfer (CT) with all transitions, we have used a recently designed procedure. ${ }^{21}$ For the 509 and $513 \mathrm{~nm}$ peaks of 3 and 4, TD-DFT predicts a promotion from the DPP (HOMO-2) to the anchoring group (LUMO). These extra transitions therefore imply a significant CT (distance $>5 \AA$ ) in a key domain of the visible spectra, confirming the improvements brought by DPP with that respect. From our calculations, there are no clear hints that the CT could be significantly different for these two dyes when absorption around $500 \mathrm{~nm}$ occurs. The Q-band also implies a CT over a significant distance for all systems but for $\mathbf{3}$, illustrating the positive impact of the "pushing" amino group. For $\mathbf{2}$ the Soret peak induces a stronger CT than for $\mathbf{1}$, which is consistent with the orbitals in Figure 4. For $\mathbf{3}$ and $\mathbf{4}$, the Soret bands implies the LUMO+2 that is alike the LUMO+1 of $\mathbf{2}$ and $\mathbf{1}$ and also the LUMO, therefore indicating an improved situation compared to DPP-free structures, which is confirmed by the larger computed CT distances.

Table 2. Summary of the theoretical results obtained at the PCM-TD-CAM-B3LYP/6$31+\mathrm{G}(\mathrm{d})$ level. The dipole-allowed vertical absorption wavelength $(\lambda$, in $\mathrm{nm})$ are listed with their oscillator strengths $(f)$ and the three largest orbital contributions in decreasing order. Only transitions with $\lambda>350 \mathrm{~nm}$ and $f>0.4$ are reported. For each transitions, charge-transfer parameters (see experimental section) have been computed: $d_{\mathrm{CT}}$, the distance (Ang.) and $q_{\mathrm{CT}}$ the transfered charge (in $e$ ). The energies of the HOMO and LUMO level (in eV) as well as the ground-state dipole moment (in Debye) are also listed on the r.h.s. of the Table. 


\begin{tabular}{|l|l|l|l|l|l|l|l|l|}
\hline Dye & $\lambda$ & $f$ & Orbitals contributions & $d_{\mathrm{CT}}$ & $q_{\mathrm{CT}}$ & HOMO & LUMO & Dipole \\
\hline $\mathbf{1}$ & 644 & 0.41 & $\mathrm{H} \rightarrow \mathrm{L} ; \mathrm{H}-1 \rightarrow \mathrm{L}+1 ; \mathrm{H}-2 \rightarrow \mathrm{L}$ & 3.19 & 0.41 & -6.15 & -2.33 & 8.47 \\
& 436 & 0.78 & $\mathrm{H} \rightarrow \mathrm{L}+1 ; \mathrm{H}-1 \rightarrow \mathrm{L}$ & 3.84 & 0.51 & & & \\
& 411 & 1.39 & $\mathrm{H}-1 \rightarrow \mathrm{L}+1 ; \mathrm{H}-2 \rightarrow \mathrm{L} ; \mathrm{H} \rightarrow \mathrm{L}+2$ & 3.87 & 0.25 & & & \\
\hline $\mathbf{2}$ & 651 & 0.73 & $\mathrm{H} \rightarrow \mathrm{L} ; \mathrm{H}-1 \rightarrow \mathrm{L}+1 ; \mathrm{H} \rightarrow \mathrm{L}+2$ & 3.69 & 0.36 & -6.01 & -2.31 & 8.10 \\
& 444 & 2.03 & $\mathrm{H}-1 \rightarrow \mathrm{L}+1 ; \mathrm{H} \rightarrow \mathrm{L}+2 ; \mathrm{H} \rightarrow \mathrm{L}$ & 7.40 & 0.46 & & & \\
& 431 & 0.88 & $\mathrm{H} \rightarrow \mathrm{L}+1 ; \mathrm{H}-1 \rightarrow \mathrm{L} ; \mathrm{H}-1 \rightarrow \mathrm{L}+2$ & 4.42 & 0.47 & & & \\
& 375 & 0.41 & $\mathrm{H}-2 \rightarrow \mathrm{L}+1 ; \mathrm{H}-1 \rightarrow \mathrm{L}$ & 3.58 & 0.63 & & & \\
\hline $\mathbf{3}$ & 608 & 0.95 & $\mathrm{H} \rightarrow \mathrm{L}+1 ; \mathrm{H} \rightarrow \mathrm{L} ; \mathrm{H}-1 \rightarrow \mathrm{L}+2$ & 1.61 & 0.61 & -6.16 & -2.35 & 8.80 \\
& 509 & 1.55 & $\mathrm{H}-2 \rightarrow \mathrm{L} ; \mathrm{H} \rightarrow \mathrm{L} ; \mathrm{H}-1 \rightarrow \mathrm{L}+2$ & 5.22 & 0.24 & & & \\
& 416 & 0.74 & $\mathrm{H}-1 \rightarrow \mathrm{L}+2 ; \mathrm{H}-2 \rightarrow \mathrm{L} ; \mathrm{H} \rightarrow \mathrm{L}$ & 9.47 & 0.25 & & & \\
& 405 & 1.47 & $\mathrm{H} \rightarrow \mathrm{L}+2 ; \mathrm{H}-1 \rightarrow \mathrm{L}+1 ; \mathrm{H}-1 \rightarrow \mathrm{L}$ & 2.15 & 0.19 & & & \\
& 388 & 0.96 & $\mathrm{H}-3 \rightarrow \mathrm{L} ; \mathrm{H}-2 \rightarrow \mathrm{L}+3 ; \mathrm{H}-2 \rightarrow \mathrm{L}+1$ & 5.94 & 0.37 & & & \\
& 380 & 0.56 & $\mathrm{H} \rightarrow \mathrm{L}+1 ; \mathrm{H} \rightarrow \mathrm{L} ; \mathrm{H} \rightarrow \mathrm{L}+3$ & 12.26 & 0.56 & & & \\
\hline $\mathbf{4}$ & 646 & 0.91 & $\mathrm{H} \rightarrow \mathrm{L}+1 ; \mathrm{H} \rightarrow \mathrm{L} ; \mathrm{H}-1 \rightarrow \mathrm{L}+2$ & 3.56 & 0.32 & -5.98 & -2.36 & 8.76 \\
& 513 & 1.54 & $\mathrm{H}-2 \rightarrow \mathrm{L} ; \mathrm{H}-3 \rightarrow \mathrm{L} ; \mathrm{H} \rightarrow \mathrm{L}+3$ & 6.11 & 0.27 & & & \\
& 428 & 0.88 & $\mathrm{H} \rightarrow \mathrm{L}+2 ; \mathrm{H}-1 \rightarrow \mathrm{L}+1 ; \mathrm{H}-1 \rightarrow \mathrm{L}$ & 4.26 & 0.47 & & & \\
& 416 & 0.50 & $\mathrm{H}-1 \rightarrow \mathrm{L}+2 ; \mathrm{H}-3 \rightarrow \mathrm{L} ; \mathrm{H} \rightarrow \mathrm{L}$ & 11.86 & 0.33 & & & \\
& 385 & 1.64 & $\mathrm{H}-4 \rightarrow \mathrm{L} ; \mathrm{H}-1 \rightarrow \mathrm{L}+2 ; \mathrm{H}-4 \rightarrow \mathrm{L}+1$ & 7.27 & 0.27 & & & \\
& 378 & 0.46 & $\mathrm{H}-2 \rightarrow \mathrm{L}+2 ; \mathrm{H}-3 \rightarrow \mathrm{L}+2 ; \mathrm{H}-3 \rightarrow \mathrm{L}+1$ & 3.26 & 0.62 & & & \\
\hline
\end{tabular}

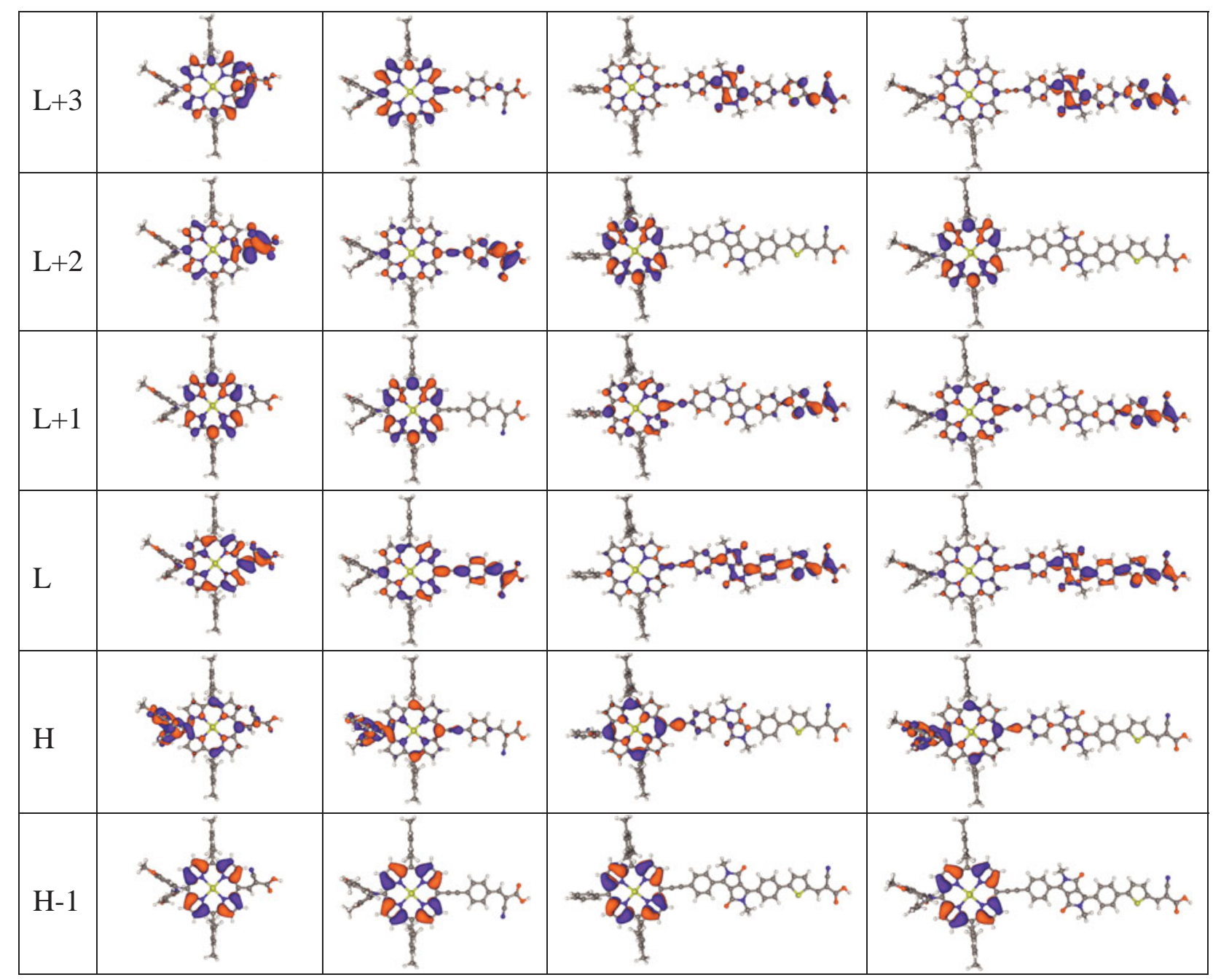




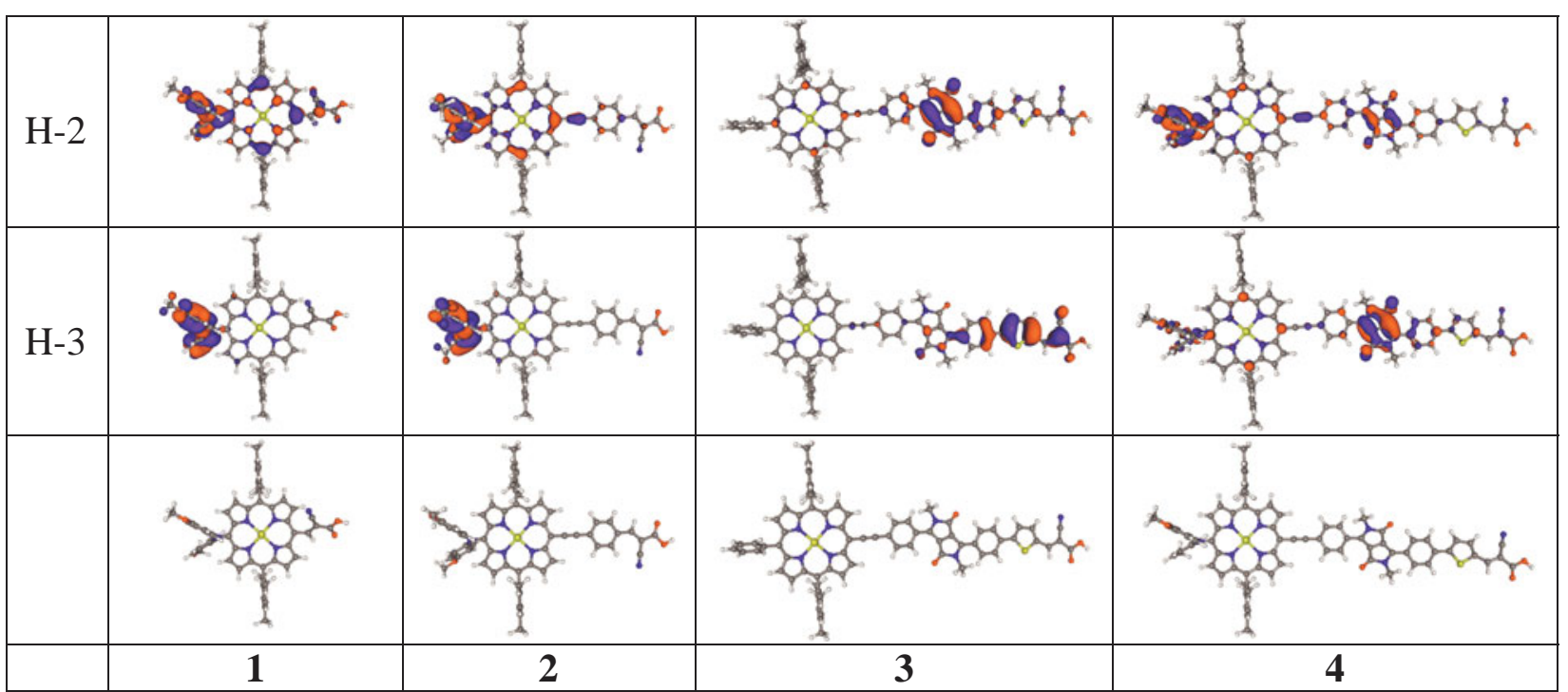

Figure 4. Graphical representation of the optimized structure and of the frontier molecular orbitals (from HOMO-3 to LUMO+3) of the porphyrin sensitizers. Branched alkyl chains were replaced by methyl groups for faster calculations.

\section{Photovoltaic measurements}

The four new porphyrins were tested as sensitizers in classical DSSC devices using a liquid electrolyte composed of $0.6 \mathrm{M}$ 1,2-dimethyl-3-butylimidazolium iodide, $0.1 \mathrm{M} \mathrm{LiI}$ and 0.05 $\mathrm{M} \mathrm{I}_{2}$ in acetonitrile and using $12 \mu \mathrm{m}$ thick $\mathrm{TiO}_{2}$ electrodes. For comparison, a reference cell sensitized with the ruthenium complex N719 was also prepared. The photocurrent densityvoltage $(\mathrm{J}-\mathrm{V})$ traces and incident photon-to-current conversion efficiency (IPCE) spectra are depicted in Figures 5 and 6 respectively and the photovoltaic data are collected in Table 3. First, we can notice that the Voc values are relatively low since they never exceed $605 \mathrm{mV}$ for all the dyes. Interestingly, the highest Voc was obtained with 4, which exhibits one of the lowest overall photo-conversion efficiencies within this series owing to a particularly poor Jsc (Table 3). Low Voc, which are quite usual with organic sensitizers, most probably stem from the high charge recombination reactions (CR) between the injected electron with the hole on the sensitizer or with the liquid electrolyte (dark current). ${ }^{22}$ Sensitizer $\mathbf{4}$ is a long rigid molecule in which the positive charge, formed upon electron injection, must be primarily located on the amino substituent (see calculations above). As a result, there is a large distance between the two charges, explaining thus the slower CR and consequently the higher Voc. ${ }^{23}$ Besides, the $\mathrm{J}-\mathrm{V}$ curves show that the dark current with porphyrin $\mathbf{4}$ is significantly lower than with the other dyes, probably due to a closer molecular packing on the $\mathrm{TiO}_{2}$ surface preventing the approach of triiodide (Figure 5). 
The low photovoltaic performances of sensitizers $\mathbf{1}$ and $\mathbf{4}$ originate in the poor photocurrent. Inspection of the distribution of the LUMO orbitals reveals that the electronic coupling with the $\mathrm{TiO}_{2}$ conduction band must be large and certainly similar within this series of dyes, since all the LUMO orbitals significantly extend on the anchoring group allowing thus a good mixing of the wave function of the excited-state with the accepting levels of the semiconductor (Table 3). Conversely, sensitizers $\mathbf{1}$ and $\mathbf{4}$ display lower light harvesting efficiencies compared to those of the sensitizers $\mathbf{2}$ and $\mathbf{3}$ and this certainly explains the lower photocurrents measured with 1 and 4 (Figure 3). Another important difference of 1 and 4 compared to $\mathbf{2}$ and particularly $\mathbf{3}$ (the best dye) is the weak driving force of the dye regeneration reaction (Table 1). Therefore, these two dyes are certainly limited by a weak electron collection efficiency owing to a sluggish reaction of iodide with the oxidized sensitizer after electron injection. This is reflected by the lower IPCE values recorded for $\mathbf{1}$ and 4 compared to those of the other dyes (Figure 6). Introduction of a weaker electron donor substituent than dianisylamine would raise the oxidation potential and enlarge the driving force of the limiting dye regeneration reaction. This is particularly exacerbated by the presence of the DPP unit in $\mathbf{4}$, which is known to be a rather electron donating unit in polymers for organic solar cells. ${ }^{24}$

The dye regeneration reaction of porphyrin $\mathbf{2}$ is slightly more exergonic, therefore this dye consistently exhibits a higher, albeit low, photocurrent density compared to that with $\mathbf{1}$ and $\mathbf{4}$ (Tables 1 and 3). Although not optimized in term of electron injection Gibbs free energy, the highest photo-conversion efficiency was obtained with porphyrin $\mathbf{3}$. This is clearly confirmed by the addition of $0.5 \mathrm{M}$ tert-butylpyridine in the electrolyte, which decreases the photocurrent density by more than $50 \%$ owing to the upward band bending, which narrows the energy difference between the LUMO of the dye and the edge of the $\mathrm{TiO}_{2}$ conduction band. The decrease of the overall photo-conversion efficiency upon tert-butylpyridine addition in the electrolyte is only observed with dyes $\mathbf{1}$ and $\mathbf{3}$, whose electron injection Gibbs free energy is somewhat not too large. However, $\mathbf{3}$ exhibits a broad IPCE trace spanning a large spectral window from 380 to $700 \mathrm{~nm}$ (Figures 3 and 6). This highlights the beneficial effect of the DPP moiety which fills the absorption gap of the porphyrin around $500 \mathrm{~nm}$. This positive effect can be also observed with $\mathbf{4}$, although less marked because its IPCE values are lower than those of $\mathbf{3}$ (Figure 6). The structure of $\mathbf{2}$ is related to the efficient porphyrin sensitizer YD2 developed by Diau and co-workers and which gives a 8.8\% photo-conversion efficiency. ${ }^{4}$ YD2 differs from 2 by the meso phenyl substituents on the porphyrin (tert-butyl in meta for YD2 versus methyl in ortho and para for 2) and on the substituents of the amino 
electron releasing unit (hexyl chains for YD2 versus methoxy groups for 2) and finally by the anchoring group (simple carboxylic acid for YD2 versus cyanoacrylic acid for 2). This study reveals, that the determining parameter is most certainly the replacement of the methoxy groups by the hexyl chains on the diarylamino pushing unit, because these subtituents control both the efficiency of the regeneration reaction (via oxidation potential of the dye) and probably the degree of aggregation and as important the surface protection against triiodide approach (to prevent losses by dark current).

Table 3. Photovoltaic performances of the dyes recorded under AM1.5 $\left(100 \mathrm{~mW} / \mathrm{cm}^{2}\right.$ illumination); ${ }^{\mathrm{a}}$ in presence of CDCA; ${ }^{\mathrm{b}}$ without CDCA (see experimental, part).

\begin{tabular}{|c|c|c|c|c|}
\hline Dye & $\begin{array}{c}\text { Voc } \\
(\boldsymbol{m} \boldsymbol{V})\end{array}$ & $\begin{array}{c}\boldsymbol{J} \boldsymbol{J} \boldsymbol{c} \\
\left(\boldsymbol{m A} / \mathbf{c m}^{2}\right)\end{array}$ & $\begin{array}{c}\boldsymbol{f f} \\
(\%)\end{array}$ & $\begin{array}{c}\eta \\
(\%)\end{array}$ \\
\hline $\mathbf{1}^{\mathbf{a}}$ & 545 & 6.02 & 73.1 & 2.40 \\
\hline $\mathbf{2}^{\mathbf{a}}$ & 535 & 9.10 & 69.2 & 3.37 \\
\hline $\mathbf{3}^{\text {a }}$ & 555 & 12.88 & 72.7 & 5.19 \\
\hline $\mathbf{4}^{\text {a }}$ & 605 & 5.50 & 76.6 & 2.55 \\
\hline $\mathbf{N 7 1 9}^{\mathbf{b}}$ & 645 & 21.31 & 63.6 & 8.75 \\
\hline
\end{tabular}

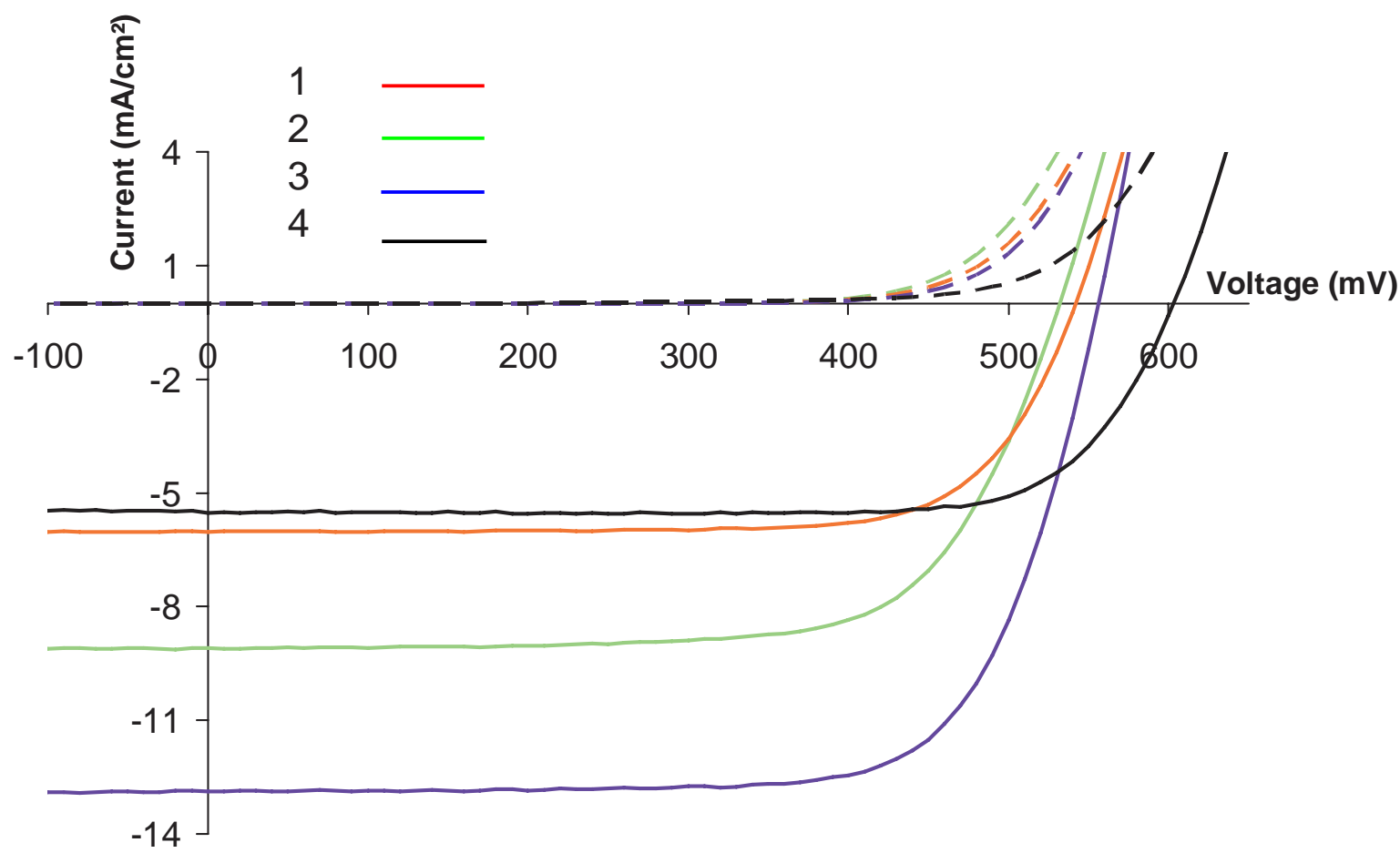

Figure 5. Current/Voltage characteristics of the porphyrin sensitizers recorded under AM1.5 (straight line) and under the dark (dashed line). 


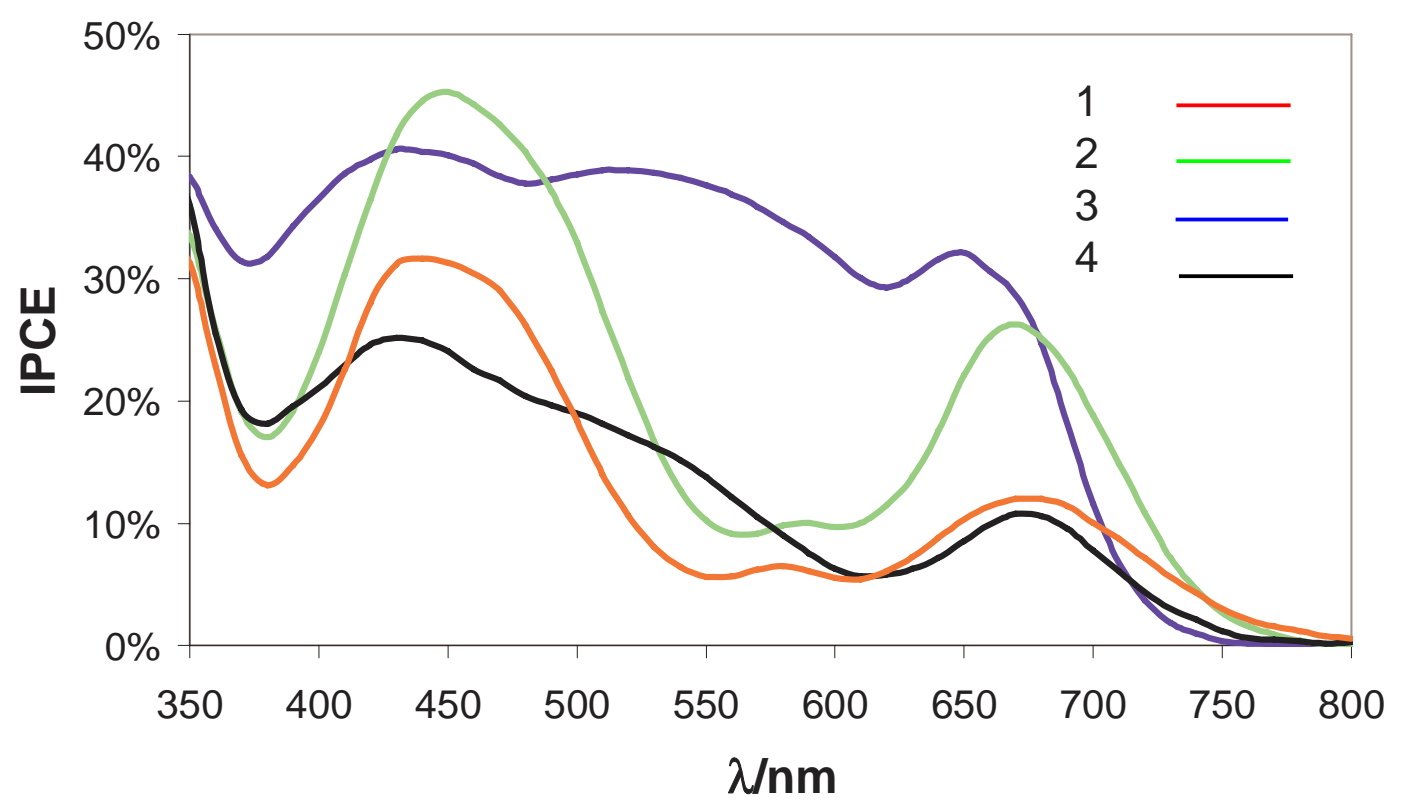

Figure 6. Photoaction spectra of the porphyrin sensitizers.

\section{Conclusions}

This work illustrates that the photo-activity of push-pull porphyrin dyes in DSSC can be extended by filling their usual transparent window around $500 \mathrm{~nm}$ with a DPP moiety placed, as a conjugated spacer, between the porphyrin core and the anchoring group. The main weak point of the present dyes lies in their relatively cathodic oxidation potentials, making the regeneration reaction particularly inefficient and subsequently limiting the charge collection efficiency. This drawback essentially stems from the too strong electron releasing unit of dianisylamine. Although porphyrin $\mathbf{4}$ is the one of the less efficient dyes within these series, it is probably one of the most promising systems, because if one raises its oxidation potential by diminishing the electron donating strength of the push substituent, it is certainly possible to significantly increase the photocurrent as the absorption window and the injection efficiency are quite large. These structure-property relationships may be useful for the future molecular design of better performing porphyrin sensitizers for DSSC.

\section{Acknowledgements}

The authors wish to thank the ANR HABISOL (program Asyscol, $\mathrm{n}^{\circ}$ ANR-08HABISOL-002) for financial support. D.J. is indebted to the Région des Pays de la Loire for financial support in the framework of a recrutement sur poste stratégique. This research used 
resources of the GENCI-CINES/IDRIS (Grant c2011085117) and of the CCIPL (Centre de Calcul Intensif des Pays de Loire).

\section{Supporting information materials}

Supporting information for this article is available on the WWW under http://www.chemsuschem.org or from the authors.

\section{References:}

[1] A. Hagfeldt, G. Boschloo, L. Sun, L. Kloo H. Pettersson, Chem. Rev. 2010, 110, 65956663.

[2] A. Mishra, M. K. R. Fischer P. Bauerle, Angew. Chem., Int. Ed. 2009, 48, 2474-2499.

[3] W. Zeng, Y. Cao, Y. Bai, Y. Wang, Y. Shi, M. Zhang, F. Wang, C. Pan P. Wang, Chem. Mater. 2010, 22, 1915-1925; S. Ito, H. Miura, S. Uchida, M. Takata, K. Sumioka, P. Liska, P. Comte, P. Pechy M. Gratzel, Chem. Commun. 2008, 5194-5196.

[4] T. Bessho, S. M. Zakeeruddin, C.-Y. Yeh, E. W.-G. Diau M. Grätzel, Angew. Chem., Int. Ed. 2010, 49, 6646-6649.

[5] Y.-C. Chang, C.-L. Wang, T.-Y. Pan, S.-H. Hong, C.-M. Lan, H.-H. Kuo, C.-F. Lo, H.-Y. Hsu, C.-Y. Lin E. W.-G. Diau, Chem. Commun. 2011, 47, 8910-8912.

[6] A. Yella, H.-W. Lee, H. N. Tsao, C. Yi, A. K. Chandiran, M. K. Nazeeruddin, E. W.G. Diau, C.-Y. Yeh, S. M. Zakeeruddin M. Grätzel, Science 2011, 334, 629-634.

[7] M. G. Walter, A. B. Rudine C. C. Wamser, J. Porphyrins Phthalocyanines 2010, 14, 759-792; M. V. Martinez-Diaz, G. de la Torre T. Torres, Chem. Commun. 2010, 46, 7090-7108; H. Imahori, T. Umeyama S. Ito, Acc. Chem. Res. 2009, 42, 1809-1818; C.L. Wang, Y.-C. Chang, C.-M. Lan, C.-F. Lo, E. W.-G. Diau C.-Y. Lin, Energy Environ. Sci. 2011, 4, 1788-1795; K. K. Pasunooti, J.-L. Song, H. Chai, P. Amaladass, W.-Q. Deng X.-W. Liu, J. Photochem. Photobiol., A 2011, 218, 219-225; J. A. Mikroyannidis, G. Charalambidis, A. G. Coutsolelos, P. Balraju G. D. Sharma, J. Power Sources 2011, 196, 6622-6628; S. Mathew, H. Iijima, Y. Toude, T. Umeyama, Y. Matano, S. Ito, N. V. Tkachenko, H. Lemmetyinen H. Imahori, J. Phys. Chem. C 2011, ACS ASAP; Y. Liu, H. Lin, J. T. Dy, K. Tamaki, J. Nakazaki, D. Nakayama, S. Uchida, T. Kubo H. Segawa, Chem. Commun. 2011, 47, 4010-4012; M. J. Lee, K. D. Seo, H. M. Song, M. S. Kang, Y. K. Eom, H. S. Kang H. K. Kim, Tetrahedron Lett. 2011, 52, 3879-3882; H. Imahori, H. Iijima, H. Hayashi, Y. Toude, T. Umeyama, Y. Matano S. Ito, ChemSusChem 2011, 4, 797-805; H. Imahori, Key Eng. Mater. 2011, 451, 29-40; E. M. Barea, V. Gonzalez-Pedro, T. Ripolles-Sanchis, H.-P. Wu, L.-L. Li, C.-Y. Yeh, E. W.-G. Diau J. Bisquert, J. Phys. Chem. C 2011, 115, 10898-10902; N. Xiang, X. Huang, X. Feng, Y. Liu, B. Zhao, L. Deng, P. Shen, J. Fei S. Tan, Dyes Pigm. 2010, 88, 75-83; S.-L. Wu, H.-P. Lu, H.-T. Yu, S.-H. Chuang, C.-L. Chiu, C.-W. Lee, E. W.-G. Diau C.-Y. Yeh, Energy Environ. Sci. 2010, 3, 949-955; X.-F. Wang H. Tamiaki, Energy Environ. Sci. 2010, 3, 94-106; C. Y. Lee J. T. Hupp, Langmuir 2009, 
26, 3760-3765; J. Warnan, F. Buchet, Y. Pellegrin, E. Blart F. Odobel, Org. Lett. 2011, 13, 3944-3947; F. Odobel, E. Blart, M. Lagree, M. Villieras, H. Boujtita, N. El Murr, S. Caramori C. Alberto Bignozzi, J. Mater. Chem. 2003, 13, 502-510.

[8] F.-L. Guo, S.-Y. Qu, W.-J. Wu, J. Li, W.-J. Ying J.-L. Hua, Synth. Met. 2010, 160, 1767-1773; C. Kanimozhi, P. Balraju, G. D. Sharma S. Patil, J. Phys. Chem. C 2010, 114, 3287-3291; S. Qu, W. Wu, J. Hua, C. Kong, Y. Long H. Tian, J. Phys. Chem. C 2009, 114, 1343-1349.

[9] J. S. Lindsey, Acc. Chem. Res. 2009, 43, 300-311; B. J. Littler, Y. Ciringh J. S. Lindsey, J. Org. Chem. 1999, 64, 2864-2872.

[10] D. P. Arnold, R. C. Bott, H. Eldridge, F. M. Elms, G. Smith M. Zojaji, Aust. J. Chem. 1997, 50, 495 - 504.

[11] J. F. Hartwig, Acc. Chem. Res. 2008, 41, 1534-1544; J. F. Hartwig, Acc. Chem. Res. 1998, 31, 852-860.

[12] R. Grigg, G. Shelton, A. Sweeney A. W. Johnson, Perkin Trans. 1 1972, 1789-1799.

[13] R. W. Wagner, T. E. Johnson, F. Li J. S. Lindsey, J. Org. Chem. 1995, 60, 5266-5273.

[14] E. Q. Guo, P. H. Ren, Y. L. Zhang, H. C. Zhang W. J. Yang, Chem. Commun. 2009, 5859-5861; G. Zhang, K. Liu, Y. Li M. Yang, Polym. Int. 2009, 58, 665-673.

[15] C.-W. Lee, H.-P. Lu, C.-M. Lan, Y.-L. Huang, Y.-R. Liang, W.-N. Yen, Y.-C. Liu, Y.-S. Lin, E. W.-G. Diau C.-Y. Yeh, Chem.- Eur. J. 2009, 15, 1403-1412.

[16] C.-P. Hsieh, H.-P. Lu, C.-L. Chiu, C.-W. Lee, S.-H. Chuang, C.-L. Mai, W.-N. Yen, S.-J. Hsu, E. W.-G. Diau C.-Y. Yeh, J. Mater. Chem. 2010, 20, 1127-1134.

[17] A. Hagfeldt M. Grätzel, Chem. Rev. 1995, 95, 49-68.

[18] M. Nazeeruddin M. Grätzel, in Photofunctional Transition Metal Complexes, Springer Berlin / Heidelberg, Editon edn., 2007, vol. 123, pp. 113-175.

[19] G. Boschloo A. Hagfeldt, Acc. Chem. Res. 2009, 42, 1819-1826.

[20] N. W. Duffy, L. M. Peter, R. M. G. Rajapakse K. G. U. Wijayantha, J. Phys. Chem. B 2000, 104, 8916-8919.

[21] T. Le Bahers, C. Adamo I. Ciofini, J. Chem. Theory Comput. 2011, 7, 2498-2506.

[22] M. Miyashita, K. Sunahara, T. Nishikawa, Y. Uemura, N. Koumura, K. Hara, A. Mori, T. Abe, E. Suzuki S. Mori, J. Am. Chem. Soc. 2008, 130, 17874-17881.

[23] R. Jose, Appl. Phys. Lett. 2008, 93, 023125.

[24] D. Gendron, M. Leclerc, Energy Environ. Sci. 2011, 4, 1225-1237. 


\section{Supporting Informations Materials for Diketopyrrolopyrrole-porphyrin conjugates as broadly absorbing sensitizers for dye-sensitized solar cells}

Julien Warnan, Ludovic Favereau, Frédéric Meslin, Marjorie Severac, Errol Blart, Yann Pellegrin, Denis Jacquemin* and Fabrice Odobel*.

Université de Nantes, CNRS, Chimie et Interdisciplinarité: Synthèse, Analyse, Modélisation (CEISAM), UMR CNRS n ${ }^{\circ}$ 6230, 2, rue de la Houssinière - BP 92208 - 44322 Nantes Cedex 3, France. Tel: +33(0)2511254 29. Fax: +33(0)251125402. E-mail: Fabrice.Odobel@univ-nantes.fr.

General remarks: ${ }^{1} \mathrm{H}$ and ${ }^{13} \mathrm{C}$ NMR spectra were recorded on a Bruker ARX $300 \mathrm{MHz}$. Chemical shifts for ${ }^{1} \mathrm{H}$ NMR spectra are referenced relative to residual protium in the deuterated solvent $\left(\mathrm{CDCl}_{3} \delta=7.26 \mathrm{ppm}\right.$ for ${ }^{1} \mathrm{H}$ and $\delta=77.16 \mathrm{ppm}$ for ${ }^{13} \mathrm{C}$; THF-d $8 \delta=3.57$, $1.72 \mathrm{ppm}$ for $\left.{ }^{1} \mathrm{H}\right)$. Spectra were recorded at room temperature, chemical shifts are written in ppm and coupling constants in Hz. MALDI-TOF analyses were performed on a Bruker Ultraflex III, microTOF Q spectrometer in positive linear mode at $20 \mathrm{kV}$ acceleration voltage with 2,5-dihydroxybenzoic acid (DHB) or dithranol as matrix. Electrochemical measurements were performed with a potentiostat-galvanostat AutoLab PGSTAT 302N controlled by resident GPES software (General Purpose Electrochemical System 4.9) using a conventional singlecompartment three-electrode cell. The working electrode was a FTO coated glass plate, with a layer of mesoporous $\mathrm{TiO}_{2}$ (Ti Nanoxide T/SP $13 \mathrm{~nm}$ ), dyed with $\mathbf{1}, \mathbf{2}, \mathbf{3}$ and $\mathbf{4}$. The auxiliary was a Pt plate of $1 \mathrm{~cm}^{2}$ and the reference electrode was the saturated potassium chloride calomel electrode (SCE). The supporting electrolyte was $0.1 \mathrm{~N} \mathrm{Bu}_{4} \mathrm{NPF}_{6}$ in $\mathrm{CH}_{2} \mathrm{Cl}_{2}$ and solutions were purged with argon before the measurements. All potentials are quoted relative to SCE. In all the experiments the scan rate was $100 \mathrm{mV} / \mathrm{s}$. UV-Visible absorption spectra were recorded on a $U V-2401 P C$ Shimadzu spectrophotometer. Fluorescence spectra were recorded on a SPEX Fluoromax fluorimeter. Infrared spectra (IR) were recorded on a BRUKER Vector 22 spectrometer; frequencies are reported in $\mathrm{cm}^{-1}$. Thin-layer chromatography (TLC) was performed on aluminium sheets precoated with Merck 5735 Kieselgel $60 \mathrm{~F}_{254}$. Column chromatography was carried out either with Merck 5735 Kieselgel 
60F (0.040-0.063 mm mesh). Chemicals were purchased from Sigma-Aldrich or Alfa Aesar and used as received. The resin Bio-Beads ${ }^{\circledR}$ S-X3 was purchased from Bio-Rad Laboratories. Chenodeoxycholic acid and titanium dioxide screen printing pastes were purchased from Solaronix SA (Switzerland) and Dyesol SA (Australia). Compounds $\mathbf{5}^{1}$ and $\mathbf{1 1}^{2,3}$ were prepared according to literature methods.

Fabrication of the Dye-Sensitized Solar Cells: Conductive glass substrates (F-doped $\left.\mathrm{SnO}_{2}\right)$ were purchased from Pilkington (TEC 8 , sheet resistance $8 \Omega /$ square). Conductive glass substrates were successively cleaned by sonication in soapy water, then ethanol for $10 \mathrm{~min}$ before being fired at $450{ }^{\circ} \mathrm{C}$ for $30 \mathrm{~min}$. Once cooled down to room temperature, FTO plates were rinsed with ethanol and dried in ambient air. $\mathrm{TiO}_{2}$ films were then prepared in three steps. A first treatment is applied by immersion for $30 \mathrm{~min}$ in an aqueous $\mathrm{TiCl}_{4}$ solution at $80{ }^{\circ} \mathrm{C}$. Layers of $\mathrm{TiO}_{2}$ were then screen printed with transparent colloidal paste Ti-Nanoxide T20/SP and light scattering Ti-Nanoxide 300 as final layer, with drying steps at $150{ }^{\circ} \mathrm{C}$ for 20 min between each layer. The obtained substrates were then sintered at $450{ }^{\circ} \mathrm{C}$, following a progressive heating ramp $\left(325{ }^{\circ} \mathrm{C}\right.$ for $5 \mathrm{~min}, 375^{\circ} \mathrm{C}$ for $5 \mathrm{~min}, 450{ }^{\circ} \mathrm{C}$ for $\left.30 \mathrm{~min}\right)$. A second $\mathrm{TiCl}_{4}$ treatment was applied while cells are still hot. Thicknesses were measured by a Sloan Dektak 3 profilometer. The prepared $\mathrm{TiO}_{2}$ electrodes were soaked while still hot $\left(80{ }^{\circ} \mathrm{C}\right)$ in a $0.16 \mathrm{mM}$ solution of each dye during $16 \mathrm{~h}$. A mixture of distilled dichloromethane and tetrahydrofuran was used (3/1, v/v) for new dyes bath preparation. In case of co-adsorption, required quantity of chenodeoxycholic acid $(0.8 \mathrm{mM})$ was added to the bath before soaking.For N719 bath a mixture of distilled $t$-butanol and acetonitrile (1/1, v/v) was used $(0.25 \mathrm{mM})$.

Electrolyte used are composed of: 0.6 M 1,2-dimethyl-3-butylimidazolium iodide, 0.1 M LiI and $0.05 \mathrm{M} \mathrm{I}_{2}$ in acetonitrile. Counter electrode were prepared by chemical deposition of platinum from hexachloroplatinic acid in distilled isopropanol (2 $\mathrm{mg}$ per $\mathrm{mL}$ ). The two electrodes were placed on top of each other using a thin transparent film of Surlyn polymer (DuPont, $25 \mu \mathrm{m}$ ) as a spacer to form the electrolyte space. The empty cell was tightly held, and the edges were heated to $110{ }^{\circ} \mathrm{C}$ to seal the two electrodes together. A drop of electrolyte was introduced through a predrilled hole in the counter electrode by vacuum backfilling, and was sealed afterward. The cell had an active area of $c a .0 .25 \mathrm{~cm}^{2}$.

The current-voltage characteristics were determined by applying an external potential bias to the cell and measuring the photocurrent using a Keithley model 2400 digital source meter. 
The solar simulator is an Oriel Lamp calibrated to $100 \mathrm{~mW} / \mathrm{cm}^{2}$. The overall conversion efficiency $(\eta)$ of the photovoltaic cell is calculated from the integral photocurrent density $\left(\mathrm{J}_{\mathrm{sc}}\right)$, the open-circuit photovoltage $\left(\mathrm{V}_{\mathrm{oc}}\right)$, the fill factor of the cell $(\mathrm{FF})$, and the intensity of the incident light $\left(\mathrm{I}_{\mathrm{Ph}}\right)$.

\section{Synthesis:}

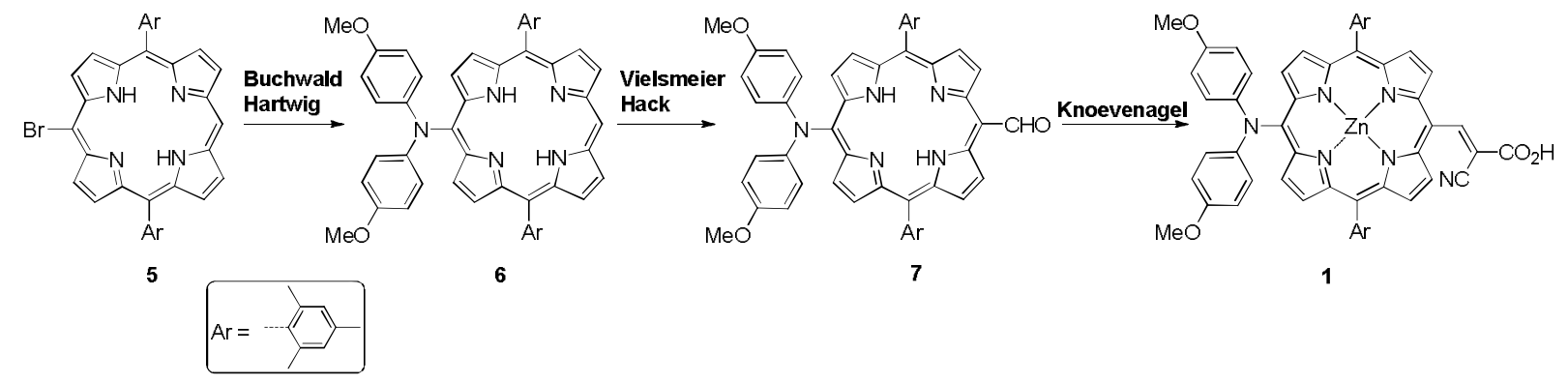

\section{5,15-dimesityl-10-(bis(4-methoxyphenyl)amino)porphyrin (6)}

Porphyrin 5 (89 mg, $0.140 \mathrm{mmol}$ ), 4,4'-dimethoxyphenylamine (98 mg, $0.427 \mathrm{mmol}$ ), dry caesium carbonate $(65 \mathrm{mg}, 0.200 \mathrm{mmol})$, DPEphos $(5.8 \mathrm{mg}, 0.011 \mathrm{mmol})$ and $\mathrm{Pd}(\mathrm{OAc})_{2}(1.7$ $\mathrm{mg}, 0.008 \mathrm{mmol}$ ) were placed in an oven-dried Schlenk tube. $9 \mathrm{~mL}$ of dry THF was added and the mixture was refluxed for $24 \mathrm{~h}$ under nitrogen atmosphere. The solvent was removed under reduced pressure and the residue was purified by flash chromatography (silica gel, petroleum spirit/dichloromethane, 6/4) to give the title compound as a green solid (93 mg, $85 \%)$.

${ }^{1} \mathbf{H}$ NMR $\left(300 \mathrm{MHz}, \mathrm{CDCl}_{3}\right): \delta_{\mathrm{H}}=9.97(1 \mathrm{H}, \mathrm{s}), 9.15(4 \mathrm{H}, \mathrm{m}), 8.7(2 \mathrm{H}, \mathrm{d}, \mathrm{J}=4.8 \mathrm{~Hz}), 8.54$ $(2 \mathrm{H}, \mathrm{d}, \mathrm{J}=4.8 \mathrm{~Hz}), 7.22(4 \mathrm{H}, \mathrm{s}), 7.19(4 \mathrm{H}, \mathrm{d}, \mathrm{J}=9.0 \mathrm{~Hz}), 6.68(4 \mathrm{H}, \mathrm{d}, \mathrm{J}=9.3 \mathrm{~Hz}), 3.66(6 \mathrm{H}$, s), $2.57(6 \mathrm{H}, \mathrm{s}), 1.78(12 \mathrm{H}, \mathrm{s}),-2.6(2 \mathrm{H}, \mathrm{s})$. MALDI-TOF: m/z calculated for 774.3803 $[\mathrm{MH}]^{+}$, Found $774.3808[\mathrm{MH}]^{+}, \Delta=0.6 \mathrm{ppm}$.

\section{0,20-dimesityl-15-(bis(4-methoxyphenyl)amino)porphyrin-5-carboxaldehyde (7)}

Copper insertion in compound $6(367 \mathrm{mg}, 0.47 \mathrm{mmol})$ was carried out as usual with $\mathrm{Cu}(\mathrm{OAc})_{2} .2 \mathrm{H}_{2} \mathrm{O}(86 \mathrm{mg}, 0.47 \mathrm{mmol})$ in a mixture of methanol and dichloromethane (4/6). The coordinated macrocycle was obtained in $100 \%$ yield. In an oven-dried flask of $100 \mathrm{~mL}$, $7.5 \mathrm{~mL}$ of dry dichloromethane and $7.5 \mathrm{~mL}$ of distilled dimethylformamide were cooled to $0{ }^{\circ} \mathrm{C}$ before $10.6 \mathrm{~mL}$ of dry $\mathrm{POCl}_{3}$ were added dropwise to the solution. The reaction mixture was stirred for $0.5 \mathrm{~h}$ at $0{ }^{\circ} \mathrm{C}$ then the porphyrin (345 mg, $\left.0.41 \mathrm{mmol}\right)$, dissolved in $60 \mathrm{~mL}$ of dry and degassed dichloromethane at $0{ }^{\circ} \mathrm{C}$, was added. The solution was refluxed for $2 \mathrm{~h}$ and cooled to room temperature. The reaction mixture was poured in $750 \mathrm{~mL}$ of saturated aqueous 
sodium acetate and refluxed. After one hour dichloromethane was added and the organic layer was washed with water twice and concentrated under reduced pressure. The crude product was then purified by flash column chromatography (silica gel, petroleum spirit/dichloromethane, 6/4) to give the intermediate porphyrin (285 mg, 80\%).

The porphyrin (142 mg, $0.16 \mathrm{mmol}$ ) was dissolved in $142 \mathrm{~mL}$ of dichloromethane and $\mathrm{H}_{2} \mathrm{SO}_{4}$ $(0.44 \mathrm{~mL}, 0.82 \mathrm{mmol})$ was added. The solution was stirred for $0.5 \mathrm{~h}$ shielded from light under argon atmosphere. The organic layer was washed with water and concentrated under reduced pressure. The crude product was then purified by flash column chromatography (silica gel, petroleum spirit/dichloromethane, 7/3) to give the title compound as a green solid (115 mg, $87 \%)$.

${ }^{1}$ H NMR $\left(300 \mathrm{MHz}, \mathrm{CDCl}_{3}\right): \delta_{\mathrm{H}}=12.34(1 \mathrm{H}, \mathrm{s}), 9.84(2 \mathrm{H}, \mathrm{d}, \mathrm{J}=4.8 \mathrm{~Hz}), 8.98(2 \mathrm{H}, \mathrm{d}, \mathrm{J}=4.8$ $\mathrm{Hz}), 8.71(2 \mathrm{H}, \mathrm{d}, \mathrm{J}=4.5 \mathrm{~Hz}), 8.32(2 \mathrm{H}, \mathrm{d}, \mathrm{J}=4.5 \mathrm{~Hz}), 7.26(4 \mathrm{H}, \mathrm{s}), 7.23(4 \mathrm{H}, \mathrm{d}, \mathrm{J}=8.4 \mathrm{~Hz})$, $6.76(4 \mathrm{H}, \mathrm{d}, \mathrm{J}=8.4 \mathrm{~Hz}), 3.73(6 \mathrm{H}, \mathrm{s}), 2.6(6 \mathrm{H}, \mathrm{s}), 1.83(12 \mathrm{H}, \mathrm{s}),-1.2(2 \mathrm{H}, \mathrm{s})$. MALDI-TOF: $\mathrm{m} / \mathrm{z}$ Calculated for $802.3752[\mathrm{MH}]^{+}$, Found $802.3766[\mathrm{MH}]^{+}, \Delta=1.7 \mathrm{ppm}$.

\section{Zinc(II) 2-cyano-3-(5'-(10',20'-dimesityl-15'-(bis(4 methoxyphenyl)amino)porphyrin)) acrylic acid (1)}

Porphyrin 7 (30 mg, $0.037 \mathrm{mmol})$ and 2-cyanoacetic acid (2.6 mg, $0.11 \mathrm{mmol}$ ) were introduced in a round-bottom flask under a nitrogen atmosphere, followed by $10 \mathrm{~mL}$ of dry acetonitrile. Dry piperidine $(0.08 \mathrm{~mL})$ was added and the solution was refluxed for $12 \mathrm{~h}$. After cooling down to room temperature the solvent was evaporated. The mixture was then dissolved in dichloromethane and washed with aqueous phosphoric acid (85\% w.), with water, and eventually dried over anhydrous $\mathrm{Na}_{2} \mathrm{SO}_{4}$. The crude product was then purified by flash column chromatography (silica gel, methanol/dichloromethane, 1/9) to give the desired compound $(20 \mathrm{mg}, 62 \%)$. Zinc insertion in the free base porphyrin was carried out as usual with $\mathrm{Zn}(\mathrm{OAc})_{2} \cdot 2 \mathrm{H}_{2} \mathrm{O}(25 \mathrm{mg}, 0.11 \mathrm{mmol})$ in a mixture of methanol/dichloromethane (5/5). The title compound was obtained in $100 \%$ yield.

${ }^{1} \mathbf{H}$ NMR (300 MHz, $\left.\mathrm{CDCl}_{3}\right): \delta_{\mathrm{H}}=10.80(1 \mathrm{H}, \mathrm{s}), 9.38(2 \mathrm{H}, \mathrm{bs}), 9.14(2 \mathrm{H}, \mathrm{d}, \mathrm{J}=4.6 \mathrm{~Hz}), 8.59$ (2H, bs), $8.44(2 \mathrm{H}, \mathrm{d}, \mathrm{J}=3.7 \mathrm{~Hz}), 7.93(1 \mathrm{H}, \mathrm{bs}), 7.20(4 \mathrm{H}, \mathrm{s}), 7.17$ (4H, d, J = 8.9 Hz), 6.77 $(4 \mathrm{H}, \mathrm{d}, \mathrm{J}=8.9 \mathrm{~Hz}), 3.62(6 \mathrm{H}, \mathrm{s}), 2.53(6 \mathrm{H}, \mathrm{s}), 1.78(12 \mathrm{H}, \mathrm{s})$. ESI: m/z Calculated for $930.2872[\mathrm{M}]^{+}$, Found $930.2877[\mathrm{M}]^{+}, \Delta=0.5 \mathrm{ppm}$. 


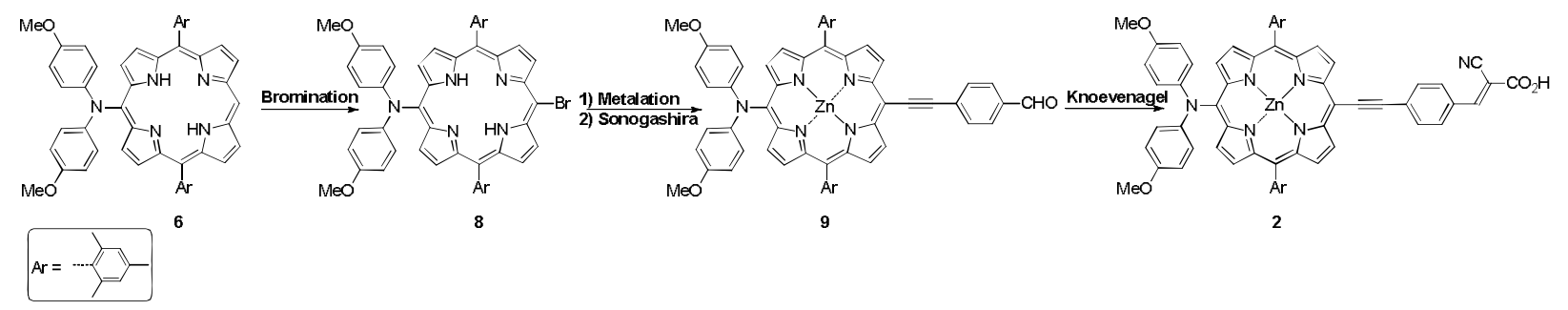

\section{5-bromo-10,20-dimesityl-15-(bis(4-methoxyphenyl)amino)porphyrin (8)}

Porphyrin 6 (60 mg, $0.078 \mathrm{mmol})$ was dissolved in $24 \mathrm{~mL}$ of dry dichloromethane under argon atmosphere and oxygen was removed by nitrogen bubbling while sonication for $15 \mathrm{~min}$. The solution was cooled to $-20{ }^{\circ} \mathrm{C}$, shielded from light, before $\mathrm{N}$-bromosuccinimide $(14 \mathrm{mg}$, $0.078 \mathrm{mmol}$ ) in $4 \mathrm{~mL}$ of dry dichloromethane was added dropwise. The reaction mixture was stirred for $2 \mathrm{~h}$ at $-20{ }^{\circ} \mathrm{C}$ and then for an additional $0.5 \mathrm{~h}$ at room temperature. The organic layer was washed with water twice then dried over anhydrous $\mathrm{Na}_{2} \mathrm{SO}_{4}$ and concentrated under reduced pressure to give the title compound as a purple solid (64 $\mathrm{mg}, 97 \%)$.

${ }^{1} \mathbf{H}$ NMR $\left(300 \mathrm{MHz}, \mathrm{CDCl}_{3}\right): \delta_{\mathrm{H}}=9.52(2 \mathrm{H}, \mathrm{d}, \mathrm{J}=4.8 \mathrm{~Hz}), 9.11(2 \mathrm{H}, \mathrm{d}, \mathrm{J}=4.8 \mathrm{~Hz}), 8.66(2 \mathrm{H}$, $\mathrm{d}, \mathrm{J}=4.8 \mathrm{~Hz}), 8.50(2 \mathrm{H}, \mathrm{d}, \mathrm{J}=4.8 \mathrm{~Hz}), 7.27(4 \mathrm{H}, \mathrm{s}), 7.24(4 \mathrm{H}, \mathrm{d}, \mathrm{J}=9.0 \mathrm{~Hz}), 6.75(4 \mathrm{H}, \mathrm{d}, \mathrm{J}=$ $9.0 \mathrm{~Hz}), 3.73(6 \mathrm{H}, \mathrm{s}), 2.62(6 \mathrm{H}, \mathrm{s}), 1.83(12 \mathrm{H}, \mathrm{s}),-2.21$ (2H, s). MALDI-TOF: m/z calculated for $851.2829[\mathrm{M}]^{+}$, Found $851.2835[\mathrm{M}]^{+}, \Delta=0.7 \mathrm{ppm}$.

\section{Zinc(II) 5-(4-formylphenylethynyl)-10,20-dimesityl-15-(bis(4-methoxyphenyl)amino)} porphyrin (9)

Zinc insertion in porphyrin $8(19 \mathrm{mg}, 0.02 \mathrm{mmol})$ was carried out as usual with $\mathrm{Zn}(\mathrm{OAc})_{2} .2 \mathrm{H}_{2} \mathrm{O}(5 \mathrm{mg}, 0.02 \mathrm{mmol})$ in $5 \mathrm{~mL}$ of a mixture of methanol and dichloromethane (5/5) at room temperature overnight. The reaction mixture was washed with $\mathrm{H}_{2} \mathrm{O}$ twice and the organic layer was dried over $\mathrm{Na}_{2} \mathrm{SO}_{4}$. The solvent was removed under reduced pressure to give the zinc porphyrin in $100 \%$ yield, which was directly engaged in the next step.

The zinc porphyrin (20 mg, $0.02 \mathrm{mmol})$, 4-ethynylbenzaldehyde (12 mg, $0.09 \mathrm{mmol})$, $\mathrm{Pd}_{2}(\mathrm{dba})_{3}(2.3 \mathrm{mg}, 0.002 \mathrm{mmol})$, triphenylphosphine $(6 \mathrm{mg}, 0.02 \mathrm{mmol})$, copper iodide $(1 \mathrm{mg}$, $0.005 \mathrm{mmol}$ ) were placed in an oven-dried Schlenk tube followed by $0.5 \mathrm{~mL}$ of dry triethylamine and $1 \mathrm{~mL}$ of dry THF. The resulting solution was freed from oxygen via 3 freeze-pump-thaw degassing cycles with argon and then refluxed for $15 \mathrm{~h}$. The solvent was removed under reduce pressure and the residue was purified by flash chromatography (silica gel, petroleum spirit/dichloromethane, $8 / 2)$ to give the title compound (7 mg, 13\%). 
${ }^{1} \mathbf{H}$ NMR $\left(300 \mathrm{MHz}, \mathrm{CDCl}_{3}\right): \delta_{\mathrm{H}}=10.11(1 \mathrm{H}, \mathrm{s}), 9.67(2 \mathrm{H}, \mathrm{d}, \mathrm{J}=4.9 \mathrm{~Hz}), 9.19(2 \mathrm{H}, \mathrm{d}, \mathrm{J}=4.9$ $\mathrm{Hz}), 8.78(2 \mathrm{H}, \mathrm{d}, \mathrm{J}=4.8 \mathrm{~Hz}), 8.56(2 \mathrm{H}, \mathrm{d}, \mathrm{J}=4.8 \mathrm{~Hz}), 8.13(2 \mathrm{H}, \mathrm{d}, \mathrm{J}=6.0 \mathrm{~Hz}), 8.06(2 \mathrm{H}, \mathrm{d}, \mathrm{J}$ $=6.0 \mathrm{~Hz}), 7.27(4 \mathrm{H}, \mathrm{s}), 7.25(4 \mathrm{H}, \mathrm{d}, \mathrm{J}=8.1 \mathrm{~Hz}), 6.73(4 \mathrm{H}, \mathrm{d}, \mathrm{J}=8.1 \mathrm{~Hz}), 3.70(6 \mathrm{H}, \mathrm{s}), 2.62$ $(6 \mathrm{H}, \mathrm{s}), 1.81(12 \mathrm{H}, \mathrm{s})$. ESI: m/z calculated for $963.3127[\mathrm{M}]^{+}$, Found $963.3126[\mathrm{M}]^{+}, \Delta=0.1$ ppm.

\section{Zinc(II) 2-Cyano-3-(4-phenylethynyl-2'-(5,15-dimesityl-10-(bis(4-methoxyphenyl)amino)} porphyrin))acrylic acid (2)

Porphyrin 9 (6 mg, $0.006 \mathrm{mmol})$ and 2-cyanoacetic acid (2 mg, $0.02 \mathrm{mmol})$ were introduced in a round-bottom flask under argon atmosphere, followed by $2 \mathrm{~mL}$ of dry acetonitrile. Dry piperidine $(0.02 \mathrm{~mL})$ was added and the solution was refluxed for $3 \mathrm{~h}$. After cooling down to room temperature the solvent was evaporated. The mixture was then dissolved in dichloromethane, washed with aqueous phosphoric acid (85\% w.), water and then dried over anhydrous $\mathrm{Na}_{2} \mathrm{SO}_{4}$. The crude product was purified by flash column chromatography (silica gel, methanol/dichloromethane, 5/95) to give the desired compound (2 mg, 31\%).

${ }^{1} \mathbf{H}$ NMR $\left(300 \mathrm{MHz}, \mathrm{CDCl}_{3}\right): \delta_{\mathrm{H}}=9.61(2 \mathrm{H}, \mathrm{d}, \mathrm{J}=4.6 \mathrm{~Hz}), 9.19(2 \mathrm{H}, \mathrm{d}, \mathrm{J}=4.9 \mathrm{~Hz}), 8.78(2 \mathrm{H}$, $\mathrm{d}, \mathrm{J}=4.8 \mathrm{~Hz}), 8.55(2 \mathrm{H}, \mathrm{d}, \mathrm{J}=4.8 \mathrm{~Hz}), 8.3(1 \mathrm{H}, \mathrm{s}), 8.18(2 \mathrm{H}, \mathrm{d}, \mathrm{J}=6.0 \mathrm{~Hz}), 8.11(2 \mathrm{H}, \mathrm{d}, \mathrm{J}=$ $6.0 \mathrm{~Hz}), 7.27(4 \mathrm{H}, \mathrm{s}), 7.25(4 \mathrm{H}, \mathrm{d}, \mathrm{J}=8.1 \mathrm{~Hz}), 6.74(4 \mathrm{H}, \mathrm{d}, \mathrm{J}=8.1 \mathrm{~Hz}), 3.70(6 \mathrm{H}, \mathrm{s}), 2.62(6 \mathrm{H}$, s), $1.83(12 \mathrm{H}, \mathrm{s})$. MALDI-TOF: m/z calculated for $1030.3180[\mathrm{M}]^{+}$, Found $1030.3165[\mathrm{M}]^{+}$, $\Delta=1.5 \mathrm{ppm}$.

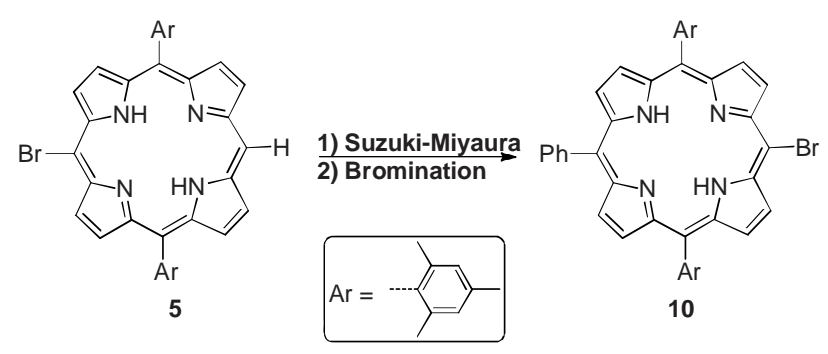

\section{5-bromo-15-phenyl-10,20-dimesitylporphyrin $(10)^{4}$}

Porphyrin 5 (80 mg, $0.13 \mathrm{mmol}$ ) was placed in an oven-dried flask of $50 \mathrm{~mL}$ under argon followed by phenyl boronic acid (156 mg, $1.30 \mathrm{mmol})$, tribasic potassium phosphate (543 mg, $2.56 \mathrm{mmol}$ ) and $30 \mathrm{~mL}$ of dry THF. The resulting mixture was freed from oxygen by nitrogen bubbling while sonicating (25 min). Then $\mathrm{Pd}\left(\mathrm{PPh}_{3}\right)_{4}(15 \mathrm{mg}, 0.013 \mathrm{mmol})$ was added in the flask. The reaction mixture was shielded from light and refluxed for $3 \mathrm{~h}$. After cooling to room temperature, the mixture was concentrated under reduced pressure. The crude product was placed in $30 \mathrm{~mL}$ of dichloromethane and the organic layer was washed with water twice, 
then dried over anhydrous $\mathrm{Na}_{2} \mathrm{SO}_{4}$ and finally concentrated under reduced pressure. The obtained purple solid was dissolved in $17 \mathrm{~mL}$ of $\mathrm{CHCl}_{3}$ under argon and $\mathrm{N}$-bromosuccinimide (23 $\mathrm{mg}, 0.13 \mathrm{mmol}$ ) was added. The resulting mixture was freed from oxygen by nitrogen bubbling while sonicating $(15 \mathrm{~min})$. Then the reaction mixture was shielded from light and stirred for $2.5 \mathrm{~h}$ at room temperature. $10 \mathrm{~mL}$ of acetone was added to the flask and the mixture was concentrated under reduced pressure. The product was then purified by flash column chromatography (silica gel, petroleum spirit/dichloromethane, 6/4) to give the title compound as a purple solid (69 $\mathrm{mg}, 73 \%)$.

Spectral analysis was similar as previously described results. ${ }^{1}$

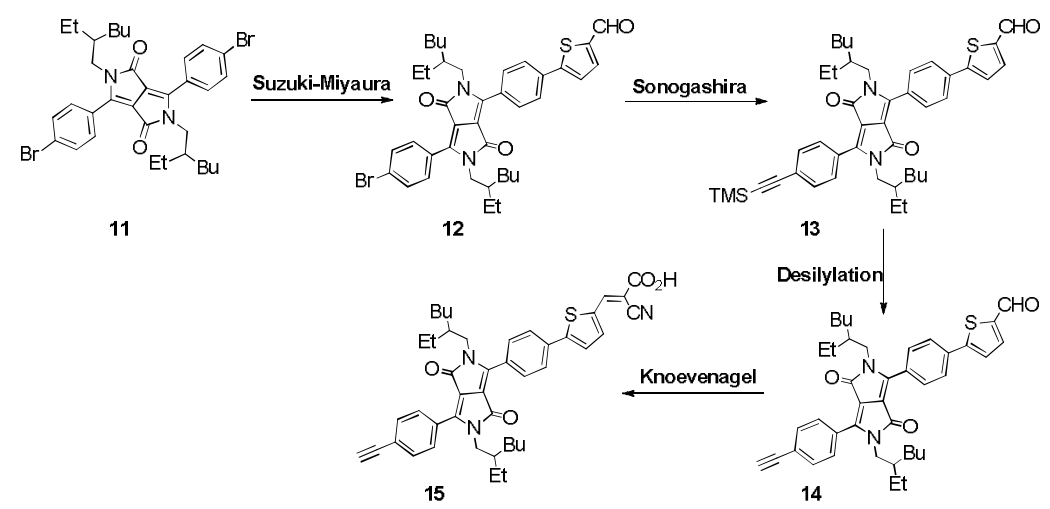

\section{5-(4-(3-(4-bromophenyl)-2,5-di(2-ethylhexyl)-pyrrolo[3,4-c]pyrrole-1,4-dione)phenyl)}

\section{thiophene-2-carboxaldehyde (12) ${ }^{5}$}

Compound 11 (199 mg, $0.30 \mathrm{mmol}), \mathrm{Pd}\left(\mathrm{PPh}_{3}\right)_{4}(24 \mathrm{mg}, 0.02 \mathrm{mmol})$, and sodium carbonate (1.02 g, $5.3 \mathrm{mmol}$ ) were solubilised in $4 \mathrm{~mL}$ of THF and $2 \mathrm{~mL}$ of $\mathrm{H}_{2} \mathrm{O}$, under argon atmosphere. The blend was heated at $45{ }^{\circ} \mathrm{C}$ for $0.5 \mathrm{~h}$ and then a solution of 4formylthiophenylboronic acid (53 mg, $0.34 \mathrm{mmol}$ ) in $4 \mathrm{~mL}$ of THF was added. The temperature was increased to $80{ }^{\circ} \mathrm{C}$ and maintained for $16 \mathrm{~h}$. Once back to room temperature, water was poured and the crude extracted with dichloromethane. After two aqueous washings, the organic phase was dried on $\mathrm{MgSO} 4$, filtered and concentrated to give a red solid. The product was then purified on silicagel column chromatography with dichloromethane as eluent. A yellow ring corresponding to the starting material was collected first, followed by an orange fraction corresponding to pure compound 12 (71 mg, 34\%).

${ }^{1} \mathbf{H}$ NMR $\left(300 \mathrm{MHz}, \mathrm{CDCl}_{3}\right): \delta_{\mathrm{H}}=9.91(1 \mathrm{H}, \mathrm{s}), 7.84(2 \mathrm{H}, \mathrm{d}, \mathrm{J}=8.6 \mathrm{~Hz}), 7.76(3 \mathrm{H}, \mathrm{m}), 7.76$ $(2 \mathrm{H}, \mathrm{d}, \mathrm{J}=8.5 \mathrm{~Hz}), 7.62(4 \mathrm{H}, \mathrm{bs}), 7.48(1 \mathrm{H}, \mathrm{d}, \mathrm{J}=4.0 \mathrm{~Hz}), 3.75(2 \mathrm{H}, \mathrm{d}, \mathrm{J}=7.8 \mathrm{~Hz}), 3.71(2 \mathrm{H}$, d, J = 7.6 Hz), $1.45(2 \mathrm{H}, \mathrm{m}), 1.08(16 \mathrm{H}, \mathrm{m}), 0.74(12 \mathrm{H}, \mathrm{m}) .{ }^{13} \mathbf{C} \mathbf{N M R}\left(75 \mathrm{MHz}, \mathrm{CDCl}_{3}\right): \delta_{\mathrm{c}}=$ 
$182.9,162.6,152.7,147.9,143.4,137.4,135.4,132.2,130.2,129.6,129.2,127.3,126.7$, $125.7,125.2,110.3,110.2,45.2,45.1,38.7,30.4,28.4,23.9,23.0,14.1,10.6$. MALDI-TOF: m/z: Calculated for: $701.2407[\mathrm{MH}]^{+}$, Found: $701.2419[\mathrm{MH}]^{+}, \Delta=1.7 \mathrm{ppm}$.

\section{5-(4-(3-(4-(trimethylsilylethynyl)phenyl)-2,5-di(2-ethylhexyl)-pyrrolo[3,4-c]pyrrole-1,4- dione)phenyl)thiophene-2-carboxaldehyde (13)}

Under argon atmosphere compound $12(30 \mathrm{mg}, 0.041 \mathrm{mmol})$ and copper iodide $(0.5 \mathrm{mg}$, $0.002 \mathrm{mmol})$ were mixed in anhydrous toluene $(4 \mathrm{~mL})$ before triethylamine $(5.4 \mathrm{mmol})$ was added. Oxygen was removed by nitrogen bubbling while sonicating for $15 \mathrm{~min}$. Then $\mathrm{Pd}\left(\mathrm{PPh}_{3}\right)_{4}(5 \mathrm{mg}, 0.004 \mathrm{mmol})$ and ethynyltrimethylsilane $(0.01 \mathrm{~mL}, 0.083 \mathrm{mmol})$ were added and the solution heated to $50{ }^{\circ} \mathrm{C}$ for roughly $16 \mathrm{~h}$. Solvent was removed under vacuum and the crude was purified by flash column chromatography (silica gel, dichloromethane) to give a red solid (30 mg, 97\%).

${ }^{1} \mathbf{H}$ NMR $\left(300 \mathrm{MHz}, \mathrm{CDCl}_{3}\right): \delta_{\mathrm{H}}=9.92(1 \mathrm{H}, \mathrm{s}), 7.87(2 \mathrm{H}, \mathrm{d}, \mathrm{J}=8.6 \mathrm{~Hz}), 7.80(2 \mathrm{H}, \mathrm{d}, \mathrm{J}=8.6$ Hz), $7.77(1 \mathrm{H}, \mathrm{d}, \mathrm{J}=4.0 \mathrm{~Hz}), 7.74(2 \mathrm{H}, \mathrm{d}, \mathrm{J}=8.5 \mathrm{~Hz}), 7.57(1 \mathrm{H}, \mathrm{d}, \mathrm{J}=8.5 \mathrm{~Hz}), 7.49(1 \mathrm{H}, \mathrm{d}, \mathrm{J}$ $=4.0 \mathrm{~Hz}), 3.75(4 \mathrm{H}, \mathrm{m}), 1.49(2 \mathrm{H}, \mathrm{m}), 1.09(16 \mathrm{H}, \mathrm{m}), 0.75(12 \mathrm{H}, \mathrm{m}), 0.27(9 \mathrm{H}, \mathrm{s}) .{ }^{13} \mathbf{C ~ N M R}$ $\left(75 \mathrm{MHz}, \mathrm{CDCl}_{3}\right): \delta_{\mathrm{c}}=182.9,162.8,162.7,152.7,148.2,147.7,143.4,137.4,135.4,132.4$, 129.6, 129.3, 128.6, 128.3, 126.7, 126.0, 125.2, 110.5, 110.3, 104.4, 97.6, 45.3, 38.7, 38.6, 30.4, 28.4, 23.9, 23.0, 14.1, 10.6, 10.5, 0.0 MALDI-TOF: m/z: Calculated for: 718.3619 [M] ${ }^{+}$, Found: $718.3613[\mathrm{M}]^{+}, \Delta=0.8 \mathrm{ppm}$.

\section{5-(4-(3-(4-ethynylphenyl)-2,5-di(2-ethylhexyl)-pyrrolo[3,4-c]pyrrole-1,4-dione)phenyl) thiophene-2-carboxaldehyde (14)}

Compound $13(22 \mathrm{mg}, 0.033 \mathrm{mmol})$ was solubilised in THF ( $3 \mathrm{~mL})$ and a solution of tetrabutylammonium fluoride $(1 \mathrm{M}$ in THF) was added $(0.045 \mathrm{~mL})$. The mixture was stirred for $2 \mathrm{~h}$, then diluted with dichloromethane and washed with water. The organic phase was dried with $\mathrm{MgSO}_{4}$, filtered and concentrated to give a red solid (21 mg, 95\%).

${ }^{1} \mathbf{H}$ NMR $\left(300 \mathrm{MHz}, \mathrm{CDCl}_{3}\right): \delta_{\mathrm{H}}=9.92(1 \mathrm{H}, \mathrm{s}), 7.85(2 \mathrm{H}, \mathrm{d}, \mathrm{J}=8.5 \mathrm{~Hz}), 7.78(2 \mathrm{H}, \mathrm{d} \mathrm{J}=8.5$ Hz), $7.76(1 \mathrm{H}, \mathrm{d} J=4.0 \mathrm{~Hz}), 7.73(2 \mathrm{H}, \mathrm{d}, \mathrm{J}=8.3 \mathrm{~Hz}), 7.58(1 \mathrm{H}, \mathrm{d}, \mathrm{J}=8.3 \mathrm{~Hz}), 7.49(1 \mathrm{H}, \mathrm{d}, \mathrm{J}$ $=4.0 \mathrm{~Hz}), 3.74(4 \mathrm{H}, \mathrm{m}), 3.21(1 \mathrm{H}, \mathrm{s}), 1.47(2 \mathrm{H}, \mathrm{m}), 1.08(16 \mathrm{H}, \mathrm{m}), 0.74(12 \mathrm{H}, \mathrm{m}) .{ }^{13} \mathbf{C} \mathbf{~ N M R}$ $\left(75 \mathrm{MHz}, \mathrm{CDCl}_{3}\right): \delta_{\mathrm{c}}=182.9,162.7,152.7,148.1,147.9,143.4,137.4,135.4,132.6,129.6$, $129.3,128.7,128.3,126.7,125.2,124.9,110.4,83.1,79.9,45.2,38.7,30.4,28.4,23.9,23.0$, 
14.1, 10.6, 10.5 MALDI-TOF: m/z: Calculated for: $647.3302[\mathrm{MH}]^{+}$, Found: 647.3314 $[\mathrm{MH}]^{+}, \Delta=1.9 \mathrm{ppm}$.

\section{2-cyano-3-(5-(4-(3-(4-ethynylphenyl)-2,5-di(2-ethylhexyl)-pyrrolo[3,4-c]pyrrole-1,4- dione)phenyl)thiophen-2-yl)acrylic acid (15)}

Molecule 14 (22 $\mathrm{mg}, 0.034 \mathrm{mmol})$ and cyanoacetic acid $(10 \mathrm{mg}, 0.10 \mathrm{mmol})$ were placed in a mixture of acetonitrile $(1 \mathrm{~mL})$ and chloroform $(2 \mathrm{~mL})$, before distilled piperidine $(0.085$ mmol) was added. The solution was refluxed for $10 \mathrm{~h}$. The solution's colour turned to deep red and the degree of advancement was followed by TLC. At room temperature dichloromethane and a diluted solution of hydrochloric acid were added before the organic phase was washed with water and dried on $\mathrm{Na}_{2} \mathrm{SO}_{4}$. After filtration and concentration the crude was purified by flash column chromatography (silica gel, dichloromethane/methanol, 9/1). After elimination of low polarity residues, a few amounts of triethylamine were added to the eluent. The obtained red fraction was washed with a hydrochloric acid solution $(1 \mathrm{~N})$, dried, filtered and concentrated to furnish a red solid (12 mg, 50\%).

${ }^{1}$ H NMR (300 MHz, THF-d8): $\delta_{\mathrm{H}}=8.37(1 \mathrm{H}, \mathrm{s}), 8.01(2 \mathrm{H}, \mathrm{d}, \mathrm{J}=8.3 \mathrm{~Hz}), 7.93(2 \mathrm{H}, \mathrm{m}), 7.89$ $(3 \mathrm{H}, \mathrm{m}), 7.71(1 \mathrm{H}, \mathrm{d}, \mathrm{J}=4.0 \mathrm{~Hz}), 7.58(2 \mathrm{H}, \mathrm{d}, \mathrm{J}=8.2 \mathrm{~Hz}), 3.82(4 \mathrm{H}, \mathrm{m}), 3.76(1 \mathrm{H}, \mathrm{s}), 1.43$ (2H, m), $1.11(16 \mathrm{H}, \mathrm{m}), 0.74(12 \mathrm{H}, \mathrm{m})$. FT-IR $\left(\mathrm{KBr}, \mathrm{cm}^{-1}\right): 2216,1703,1628,1262,1093$

MALDI-TOF: m/z: Calculated for: $713.3282[\mathrm{M}]^{+}$, Found: $713.3262[\mathrm{M}]^{+}, \Delta=2.8 \mathrm{ppm}$.

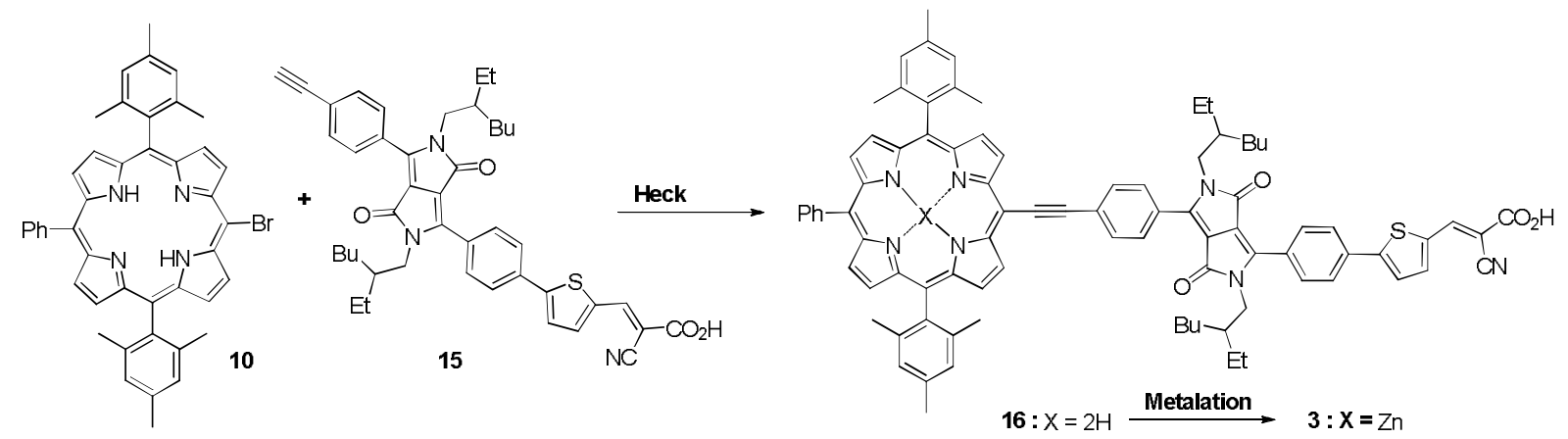

Dyad 16

DPP 15 (34 mg, $0.048 \mathrm{mmol})$, porphyrin $8(42 \mathrm{mg}, 0.06 \mathrm{mmol})$ were dissolved in a mixture of THF/MeOH $(9 / 5,14 \mathrm{~mL})$ and distilled triethylamine $(0.83 \mathrm{~mL})$ was added. Oxygen was removed by nitrogen bubbling while sonicating for $15 \mathrm{~min}$ before triphenylarsine $(55 \mathrm{mg}$, $0.18 \mathrm{mmol})$ and $\mathrm{Pd}_{2}(\mathrm{dba})_{3} . \mathrm{CHCl}_{3}(9 \mathrm{mg}, 0.009 \mathrm{mmol})$ were added. The mixture was heated to $50{ }^{\circ} \mathrm{C}$ for $2.5 \mathrm{~h}$ and solvent was removed under reduced pressure. The crude was purified by flash column chromatography (silica gel, dichloromethane/methanol, 9/1). After elimination 
of low polarity residues, a few amounts of triethylamine were added to the solvent of chromatography to give a brown solid. This fraction was washed with a hydrochloric acid solution (1N), dried, filtered and concentrated. The residue was finally purified employing Bio-Bead S-X3, in THF, to furnish a brown solid (23 mg, 36\%).

${ }^{1}$ H NMR (300 MHz, THF-d8): $\delta_{\mathrm{H}}=9.74(2 \mathrm{H}, \mathrm{d}, \mathrm{J}=4.7 \mathrm{~Hz}), 8.74(2 \mathrm{H}, \mathrm{d}, \mathrm{J}=4.7 \mathrm{~Hz}), 8.70$ $(2 \mathrm{H}, \mathrm{d}, \mathrm{J}=4.7 \mathrm{~Hz}), 8.57(2 \mathrm{H}, \mathrm{d}, \mathrm{J}=4.7 \mathrm{~Hz}), 8.34(1 \mathrm{H}, \mathrm{s}), 8.18(5 \mathrm{H}, \mathrm{m}), 8.06(2 \mathrm{H}, \mathrm{d}, \mathrm{J}=8.6$ Hz), $7.97(2 \mathrm{H}, \mathrm{d}, \mathrm{J}=8.6 \mathrm{~Hz}), 7.87(1 \mathrm{H}, \mathrm{d}, \mathrm{J}=4.1 \mathrm{~Hz}), 7.75(5 \mathrm{H}, \mathrm{m}), 7.33(4 \mathrm{H}, \mathrm{s}), 3.96(2 \mathrm{H}, \mathrm{d}$, $\mathrm{J}=7.5 \mathrm{~Hz}), 3.91(2 \mathrm{H}, \mathrm{d}, \mathrm{J}=7.5 \mathrm{~Hz}), 2.61(6 \mathrm{H}, \mathrm{s}), 1.85(12 \mathrm{H}, \mathrm{s}), 1.43(2 \mathrm{H}, \mathrm{m}), 1.11(16 \mathrm{H}, \mathrm{m})$, $0.74(12 \mathrm{H}, \mathrm{m}),-2.05(2 \mathrm{H}, \mathrm{s})$. MALDI-TOF: m/z: Calculated for: $1334.6300[\mathrm{MH}]^{+}$, Found: 1334.6315 $[\mathrm{MH}]^{+}, \Delta=1.1 \mathrm{ppm}$.

Dye 3

Molecule 16 (18 mg, $0.013 \mathrm{mmol})$ was solubilised in a mixture of $\mathrm{CH}_{2} \mathrm{Cl}_{2}$ and $\mathrm{MeOH}(1: 1,6$ $\mathrm{mL})$ and $\mathrm{Zn}(\mathrm{OAc})_{2} .2 \mathrm{H}_{2} \mathrm{O}(15 \mathrm{mg}, 0.067 \mathrm{mmol})$ was added. After $2.5 \mathrm{~h}$ of stirring at room temperature the reaction mixture was washed with $\mathrm{H}_{2} \mathrm{O}$ twice and the organic layer was dried over $\mathrm{Na}_{2} \mathrm{SO}_{4}$. Solvent was removed to give a black-green solid (18 mg, 100\%).

${ }^{1} \mathbf{H}$ NMR (300 MHz, THF-d8): $\delta_{\mathrm{H}}=9.74(2 \mathrm{H}, \mathrm{d}, \mathrm{J}=4.6 \mathrm{~Hz}), 8.73(2 \mathrm{H}, \mathrm{d}, \mathrm{J}=4.6 \mathrm{~Hz}), 8.68$ $(2 \mathrm{H}, \mathrm{d}, \mathrm{J}=4.5 \mathrm{~Hz}), 8.56(2 \mathrm{H}, \mathrm{d}, \mathrm{J}=4.5 \mathrm{~Hz}), 8.38(1 \mathrm{H}, \mathrm{s}), 8.19(2 \mathrm{H}, \mathrm{m}), 8.13(3 \mathrm{H}, \mathrm{m}), 8.08$ $(2 \mathrm{H}, \mathrm{d}, \mathrm{J}=8.4 \mathrm{~Hz}), 7.99(2 \mathrm{H}, \mathrm{d}, \mathrm{J}=8.3 \mathrm{~Hz}), 7.90(1 \mathrm{H}, \mathrm{m}), 7.71(5 \mathrm{H}, \mathrm{m}), 7.31(4 \mathrm{H}, \mathrm{s}), 3.96$ $(4 \mathrm{H}, \mathrm{m}), 2.61(6 \mathrm{H}, \mathrm{s}), 1.86(12 \mathrm{H}, \mathrm{s}), 1.43(2 \mathrm{H}, \mathrm{m}), 1.11(16 \mathrm{H}, \mathrm{m}), 0.74$ (12H, m). MALDITOF: m/z: Calculated for: $1395.5357[\mathrm{M}]^{+}$, Found: $1395.5411[\mathrm{M}]^{+}, \Delta=3.9 \mathrm{ppm}$.

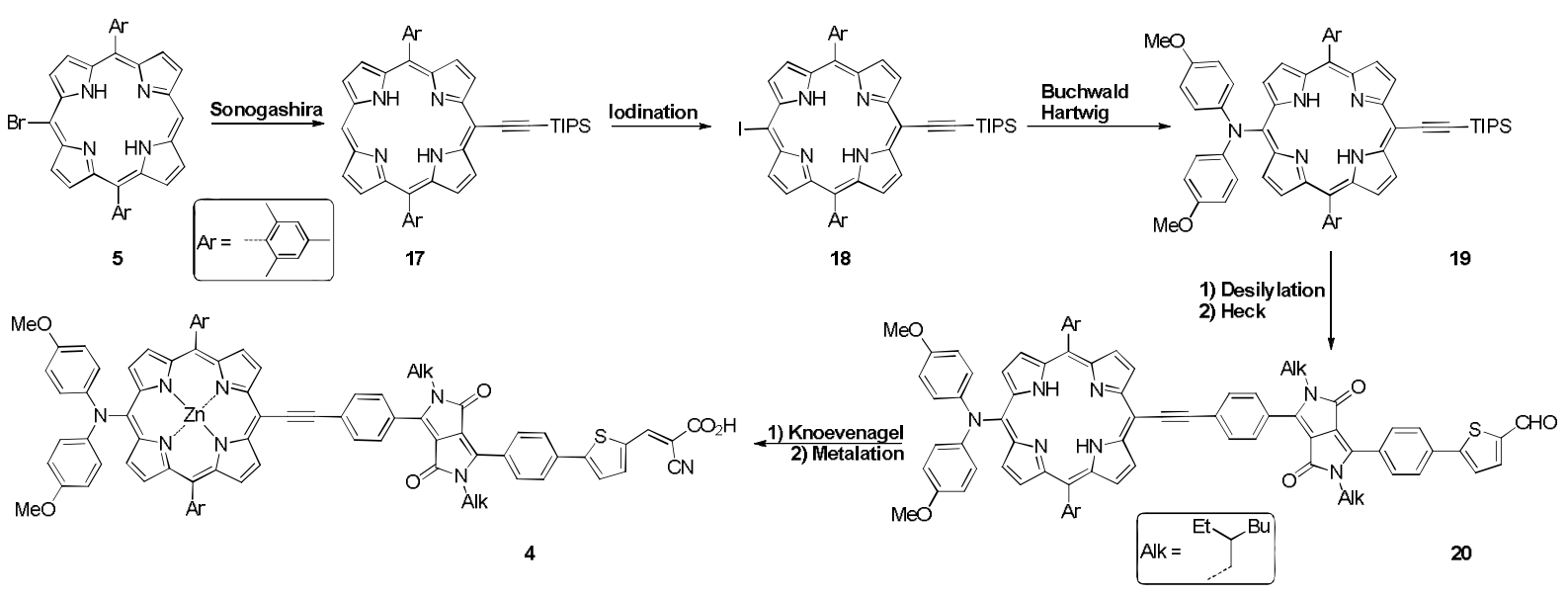




\section{5,15-dimesityl-10-(triisopropylsilylethynyl)porphyrin (17)}

A solution of $5(35 \mathrm{mg}, 0.056 \mathrm{mmol})$ in $\mathrm{CHCl}_{3}(7.3 \mathrm{~mL})$ and methanol $(0.3 \mathrm{~mL})$ was treated overnight with $\mathrm{Zn}(\mathrm{OAc})_{2} .2 \mathrm{H}_{2} \mathrm{O}(62 \mathrm{mg}, 0.28 \mathrm{mmol})$ at room temperature. The reaction mixture was washed with $\mathrm{H}_{2} \mathrm{O}$ twice and the organic layer was dried over $\mathrm{Na}_{2} \mathrm{SO}_{4}$. The solvent was removed under a reduced pressure to give the title compound as a purple solid (39 $\mathrm{mg}, 100 \%)$. The zinc porphyrin (210 mg, $0.34 \mathrm{mmol})$ was placed in an oven-dried flask of 50 $\mathrm{mL}$ under argon followed by $10 \mathrm{~mL}$ of dry THF and $3.3 \mathrm{~mL}$ of dry triethylamine. Resulting mixture was freed from oxygen by nitrogen bubbling while sonicating (15 min). Then $\mathrm{Pd}\left(\mathrm{PPh}_{3}\right)_{4} \quad(6.4 \mathrm{mg}, \quad 0.006 \mathrm{mmol})$, cooper iodide $(1.1 \mathrm{mg}, 0.006 \mathrm{mmol})$ and ethynyltriisopropylsilyl $(3.4 \mathrm{mmol})$ were added in the flask. The reaction mixture was shielded from light and stirred for $2 \mathrm{~h}$ at $68{ }^{\circ} \mathrm{C}$. After cooling to room temperature, the mixture was concentrated under reduced pressure. The crude product was placed in $60 \mathrm{~mL}$ of a mixture of dichloromethane and methanol (1/1) and $12 \mathrm{~mL}$ of a solution of hydrochloric acid $(2 \mathrm{~N})$ were added. The resulting mixture was stirred for one hour and the organic layer was washed with water twice and concentrated under reduced pressure. The product was then purified by flash column chromatography (silica gel, petroleum spirit/dichloromethane, 65/35) to give the title compound as a light purple solid (34 $\mathrm{mg}, 78 \%$ ).

${ }^{1} \mathbf{H}$ NMR (300 MHz, $\left.\mathrm{CDCl}_{3}\right): \delta_{\mathrm{H}}=10.09(1 \mathrm{H}, \mathrm{s}), 9.73(2 \mathrm{H}, \mathrm{d}, \mathrm{J}=4.5 \mathrm{~Hz}), 9.23(2 \mathrm{H}, \mathrm{d}, \mathrm{J}=4.5$ $\mathrm{Hz}), 8.81(2 \mathrm{H}, \mathrm{d}, \mathrm{J}=4.5 \mathrm{~Hz}), 8.78(2 \mathrm{H}, \mathrm{d}, \mathrm{J}=4.5 \mathrm{~Hz}), 7.31(4 \mathrm{H}, \mathrm{s}), 2.66(6 \mathrm{H}, \mathrm{s}), 1.86(12 \mathrm{H}$, s), $1.45(21 \mathrm{H}, \mathrm{m}),-2.53(2 \mathrm{H}, \mathrm{s})$. MALDI-TOF: m/z Calculated for $726.4112[\mathrm{M}]^{+}$, Found $726.4084[\mathrm{M}]^{+}, \Delta=3.9 \mathrm{ppm}$.

\section{5,15-dimesityl-10-iodo-20-(triisopropylsilylethynyl)porphyrin (18)}

Porphyrin 17 (107 mg, $0.15 \mathrm{mmol}$ ) was dissolved in $118 \mathrm{~mL}$ of dry dichloromethane under argon atmosphere and freed from oxygen by nitrogen bubbling while sonicating (15 min). Then iodine $(52 \mathrm{mg}, \quad 0.2 \mathrm{mmol}), \quad 10$ drops of dry pyridine and [bis(trifluoroacetoxy)iodo]benzene $(63.4 \mathrm{mg}, 0.15 \mathrm{mmol})$ were added to the mixture. The reaction flask was shielded from light and the reaction mixture was stirred for $20 \mathrm{~h}$ at $20^{\circ} \mathrm{C}$. The solvent was removed under reduced pressure and the crude was purified by flash chromatography (silica gel, petroleum spirit/dichloromethane, $8 / 2$ ) to give the title compound as a purple solid (100 $\mathrm{mg}, 80 \%)$.

${ }^{1} \mathbf{H}$ NMR $\left(300 \mathrm{MHz}, \mathrm{CDCl}_{3}\right): \delta_{\mathrm{H}}=9.59(2 \mathrm{H}, \mathrm{d}, \mathrm{J}=4.7 \mathrm{~Hz}), 9.55(2 \mathrm{H}, \mathrm{d}, \mathrm{J}=4.8 \mathrm{~Hz}), 8.68(2 \mathrm{H}$, $\mathrm{d}, \mathrm{J}=4.5 \mathrm{~Hz}), 8.65(2 \mathrm{H}, \mathrm{d}, \mathrm{J}=4.5 \mathrm{~Hz}), 7.28(4 \mathrm{H}, \mathrm{s}), 2.64(6 \mathrm{H}, \mathrm{s}), 1.83(12 \mathrm{H}, \mathrm{s}), 1.41(21 \mathrm{H}$, 
m), -2.22 (2H, s). MALDI-TOF: m/z calculated for $853.3157[\mathrm{MH}]^{+}$, Found $853.3181[\mathrm{MH}]^{+}$, $\Delta=2.8 \mathrm{ppm}$.

\section{5,15-dimesityl-10-(bis(4-methoxyphenyl)amino)-20-(triisopropylsilylethynyl)porphyrin} (19)

A mixture of 18 (22 mg, $0.026 \mathrm{mmol})$, 4,4'-dimethoxyphenylamine (21 mg, $0.093 \mathrm{mmol})$, dry caesium carbonate (30 mg, $0.093 \mathrm{mmol})$ and DPEphos (3.0 mg, $0.006 \mathrm{mmol})$ in $2.6 \mathrm{~mL}$ of dry THF was freed from oxygen by nitrogen bubbling while sonicating (15 min). $\operatorname{Pd}(\mathrm{OAc})_{2}(1.0$ $\mathrm{mg}, 0.0033 \mathrm{mmol}$ ) was added to the mixture. The solution was then shielded from light and refluxed for $1.5 \mathrm{~h}$. The solvent was removed under reduced pressure and the residue was purified by flash chromatography (silica gel, petroleum spirit/dichloromethane, 6/4) to give the title compound as a green solid (14 $\mathrm{mg}, 57 \%)$.

${ }^{1} \mathbf{H}$ NMR $\left(300 \mathrm{MHz}, \mathrm{CDCl}_{3}\right): \delta_{\mathrm{H}}=9.54(2 \mathrm{H}, \mathrm{d}, \mathrm{J}=4.7 \mathrm{~Hz}), 9.08(2 \mathrm{H}, \mathrm{d}, \mathrm{J}=4.7 \mathrm{~Hz}), 8.64(2 \mathrm{H}$, d, J = 4.7 Hz), $8.46(2 \mathrm{H}, \mathrm{d}, \mathrm{J}=4.7 \mathrm{~Hz}), 7.24(4 \mathrm{H}, \mathrm{d}, \mathrm{J}=9.1 \mathrm{~Hz}), 7.23(4 \mathrm{H}, \mathrm{s}),, 6.74(4 \mathrm{H}, \mathrm{d}, \mathrm{J}=$ $9.1 \mathrm{~Hz}), 3.71(6 \mathrm{H}, \mathrm{s}), 2.60(6 \mathrm{H}, \mathrm{s}), 1.81(12 \mathrm{H}, \mathrm{s}), 1.42(21 \mathrm{H}, \mathrm{m}),-1.93(2 \mathrm{H}, \mathrm{s})$. MALDI-TOF: $\mathrm{m} / \mathrm{z}$ calculated for $953.5059[\mathrm{M}]^{+}$, Found $953.5041[\mathrm{M}]^{+}, \Delta=1.9 \mathrm{ppm}$.

\section{Dyad 20}

TBAF (0.06 mL, 1M in THF) was added to a solution of 19 (14 mg, $0.015 \mathrm{mmol})$ in $2 \mathrm{~mL}$ of dry THF. The mixture was stirred at $20{ }^{\circ} \mathrm{C}$ for 45 min under argon, shielded from light. Water and dichloromethane was poured and the organic layer was dried over anhydrous $\mathrm{Na}_{2} \mathrm{SO}_{4}$. The concentrated crude and the compound 14 (12 mg, $0.018 \mathrm{mmol})$ were dissolved in $3 \mathrm{~mL}$ of dry THF and $0.2 \mathrm{~mL}$ of dry triethylamine $(150 \mathrm{mg}, 1.5 \mathrm{mmol})$ was added. The mixture was freed from oxygen by nitrogen bubbling while sonicating (15 min). Then, $\mathrm{Pd}_{2}(\mathrm{dba})_{3}(4.6 \mathrm{mg}$, $0.0044 \mathrm{mmol})$ and $\mathrm{AsPh}_{3}(27 \mathrm{mg}, 0.088 \mathrm{mmol})$ were added to the mixture. The solution was refluxed for $5.5 \mathrm{~h}$ under argon, shielded from light. The solvent was removed under reduced pressure and the residue was purified by flash chromatography (silica gel, petroleum spirit/dichloromethane, 1/9) to give the title compound as a brown solid (3 $\mathrm{mg}, 20 \%)$.

${ }^{1} \mathbf{H}$ NMR $\left(300 \mathrm{MHz}, \mathrm{CDCl}_{3}\right): \delta_{\mathrm{H}}=9.89(1 \mathrm{H}, \mathrm{s}), 9.56(2 \mathrm{H}, \mathrm{d}, \mathrm{J}=4.7 \mathrm{~Hz}), 9.06(2 \mathrm{H}, \mathrm{d}, \mathrm{J}=4.7$ $\mathrm{Hz}), 8.67(2 \mathrm{H}, \mathrm{d}, \mathrm{J}=4.9 \mathrm{~Hz}), 8.44(2 \mathrm{H}, \mathrm{d}, \mathrm{J}=4.9 \mathrm{~Hz}), 8.12(2 \mathrm{H}, \mathrm{d}, \mathrm{J}=8.5 \mathrm{~Hz}), 8.02(2 \mathrm{H}, \mathrm{d}, \mathrm{J}$ $=8.5 \mathrm{~Hz}), 7.93(2 \mathrm{H}, \mathrm{d}, \mathrm{J}=8.5 \mathrm{~Hz}), 7.85(2 \mathrm{H}, \mathrm{d}, \mathrm{J}=8.5 \mathrm{~Hz}), 7.76(1 \mathrm{H}, \mathrm{d}, \mathrm{J}=3.9 \mathrm{~Hz}), 7.52$ $(1 \mathrm{H}, \mathrm{d}, \mathrm{J}=3.9 \mathrm{~Hz}), 7.26(4 \mathrm{H}, \mathrm{s}), 7.22(4 \mathrm{H}, \mathrm{d}, \mathrm{J}=9.1 \mathrm{~Hz}), 6.73(4 \mathrm{H}, \mathrm{d}, \mathrm{J}=9.1 \mathrm{~Hz}), 3.86(4 \mathrm{H}$, m), $3.71(6 \mathrm{H}, \mathrm{s}), 2.61(6 \mathrm{H}, \mathrm{s}), 1.42(2 \mathrm{H}, \mathrm{m}), 1.83(12 \mathrm{H}, \mathrm{s}), 1.16(16 \mathrm{H}, \mathrm{m}), 0.8(12 \mathrm{H}, \mathrm{m}),-1.78$ 
(2H, s). MALDI-TOF: m/z calculated for $1417.6797[\mathrm{M}]^{+}$, Found $1417.6777[\mathrm{M}]^{+}, \Delta=1.4$ ppm.

\section{Dyad 21}

Compound 20 (2 mg, $0.0014 \mathrm{mmol}$ ), 2-cyanoacetic acid (2.4 mg, $0.028 \mathrm{mmol}$ ) and piperidine $(0.014 \mathrm{~mL})$ in $2 \mathrm{~mL}$ of dry THF were heated to reflux, under argon atmosphere, for $8 \mathrm{~h}$. After cooling to room temperature, $\mathrm{H}_{2} \mathrm{O}$ was added and the crude product was extracted with dichloromethane. The organic layer was dried over anhydrous $\mathrm{Na}_{2} \mathrm{SO}_{4}$ and concentrated under reduced pressure. The crude was purified by flash column chromatography (silica gel, methanol/dichloromethane, 1/9) to give the title product as a brown solid (1 $\mathrm{mg}, 50 \%)$.

${ }^{1} \mathbf{H}$ NMR $\left(300 \mathrm{MHz}, \mathrm{CDCl}_{3}\right): \delta_{\mathrm{H}}=9.57(2 \mathrm{H}, \mathrm{d}, \mathrm{J}=4.5 \mathrm{~Hz}), 9.06(2 \mathrm{H}, \mathrm{d}, \mathrm{J}=4.5 \mathrm{~Hz}), 8.67(2 \mathrm{H}$, bs), $8.43(2 \mathrm{H}, \mathrm{bs}), 8.13(2 \mathrm{H}, \mathrm{d}, \mathrm{J}=7.9 \mathrm{~Hz}), 8.10(1 \mathrm{H}, \mathrm{s}), 8.02(2 \mathrm{H}, \mathrm{d}, \mathrm{J}=7.8 \mathrm{~Hz}), 7.89$ (4H, bs), $7.71(1 \mathrm{H}, \mathrm{m}), 7.53(1 \mathrm{H}, \mathrm{m}), 7.26(4 \mathrm{H}, \mathrm{s}), 7.23(4 \mathrm{H}, \mathrm{d}, \mathrm{J}=9.0 \mathrm{~Hz}), 6.74(4 \mathrm{H}, \mathrm{d}, \mathrm{J}=9.0$ Hz), 3.93 (4H, m), 3.72 (6H, s), 2.61 (6H, s), 1.84 (12H, s), 1.43 (2H, m), 1.13 (16H, m), 0.8 $(12 \mathrm{H}, \mathrm{m}),-1.74(2 \mathrm{H}, \mathrm{s})$. MALDI-TOF: m/z calculated for $1485.6933[\mathrm{MH}]^{+}$, Found $1485.6943[\mathrm{MH}]^{+}, \Delta=0.7 \mathrm{ppm}$.

\section{Dye 4}

Zinc insertion in compound 21 (1 mg, $0.0007 \mathrm{mmol})$ was carried out as usual with $\mathrm{Zn}(\mathrm{OAc})_{2}$, $2 \mathrm{H}_{2} \mathrm{O}(1 \mathrm{mg}, 0.0035 \mathrm{mmol})$ in $2 \mathrm{~mL}$ of a mixture of methanol/dichloromethane (5/5) at room temperature overnight. The reaction mixture was washed with $\mathrm{H}_{2} \mathrm{O}$ twice and the organic layer was dried over $\mathrm{Na}_{2} \mathrm{SO}_{4}$. The solvent was removed under reduced pressure to give the title compound as a light brown solid (1 mg, 100\%).

${ }^{1} \mathbf{H}$ NMR (300 MHz, THF-d8): $\delta_{\mathrm{H}}=9.64(2 \mathrm{H}, \mathrm{d}, \mathrm{J}=4.6 \mathrm{~Hz}), 9.11(2 \mathrm{H}, \mathrm{d}, \mathrm{J}=4.7 \mathrm{~Hz}), 8.62$ $(2 \mathrm{H}, \mathrm{d}, \mathrm{J}=4.9 \mathrm{~Hz}), 8.42$ (2H, d, J = 4.6 Hz), 8.15 (3H, m), 8.04 (2H, m), 7.89 (4H, bs), 7.65 $(1 \mathrm{H}, \mathrm{m}), 7.51(1 \mathrm{H}, \mathrm{m}), 7.26(4 \mathrm{H}, \mathrm{s}), 7.17(4 \mathrm{H}, \mathrm{d}, \mathrm{J}=9.5 \mathrm{~Hz}), 6.68(4 \mathrm{H}, \mathrm{d}, \mathrm{J}=9.5 \mathrm{~Hz}), 3.98$ $(4 \mathrm{H}, \mathrm{m}), 3.62(6 \mathrm{H}, \mathrm{s}), 2.57(6 \mathrm{H}, \mathrm{s}), 1.86(12 \mathrm{H}, \mathrm{s}), 1.43(2 \mathrm{H}, \mathrm{m}), 1.13(16 \mathrm{H}, \mathrm{m}), 0.8(12 \mathrm{H}, \mathrm{m})$. MALDI-TOF: $\mathrm{m} / \mathrm{z}$ calculated for $1546.5990[\mathrm{M}]^{+}$, Found $1546.6023[\mathrm{M}]^{+}, \Delta=2.1 \mathrm{ppm}$. 
Theoretical Calculations: All simulations have been achieved with Gaussian09 program, ${ }^{6}$ applying default procedures, integration grids, algorithms and parameters, except for tighten SCF $\left(10^{-9}\right.$ a.u.) and internal forces $\left(10^{-5}\right.$ a.u.) convergence thresholds. We have adopted a three step strategy that is efficient to determine the UV/Vis features of most organic dyes. $^{7-10}$ The computational protocol systematically (all steps) includes a modelling of bulk solvent effects (here $\mathrm{CH}_{2} \mathrm{Cl}_{2}$ ) through the Polarizable Continuum Model (PCM) ${ }^{11}$ and proceeds as: 1) the ground-state geometrical parameters have been determined at the PBE0/6$31 \mathrm{G}(\mathrm{d})$ level [LanL2DZ pseudo-potential and basis for $\mathrm{Zn}]^{12}$ via a force-minimization process; 2) the vibrational spectrum of each derivatives has been determined analytically at the same level of theory, that is PBE0/6-31G(d), and it has been checked that all structures correspond to true minima of the potential energy surface; 3) the first ten low-lying excitedstates have been determined within the vertical TD-DFT approximation using the CAMB3LYP/6-31+G(d) [LanL2DZ pseudo-potential and basis for $\mathrm{Zn}$ ] level of approximation. ${ }^{13}$ Test calculations performed for the two smallest structure with larger basis sets have lead to trifling variations of the TD-DFT transition energies. The contour threshold selected to represent the molecular orbitals was systematically set to 0.020 a.u. During the simulations, the long alkyl chains on diketopyrrolopyrrole moiety have been replaced by methyl groups. To estimate the charge-transfer, we have used the procedure defined by Ciofini and coworkers, ${ }^{14}$ but selected (Mulliken) partial atomic charges computed for both the ground and excited states rather than the corresponding electronic densities as input.

\section{References:}

(1) Yu, L.; Muthukumaran, K.; Sazanovich, I. V.; Kirmaier, C.; Hindin, E.; Diers, J. R.; Boyle, P. D.; Bocian, D. F.; Holten, D.; Lindsey, J. S. Inorganic Chemistry 2003, 42, 6629.

(2) Guo, E. Q.; Ren, P. H.; Zhang, Y. L.; Zhang, H. C.; Yang, W. J. Chem. Commun. 2009, 5859.

(3) Zhang, G.; Liu, K.; Li, Y.; Yang, M. Polym. Int. 2009, 58, 665.

(4) Liddell, P. A.; Gervaldo, M.; Bridgewater, J. W.; Keirstead, A. E.; Lin, S.; Moore, T. A.; Moore, A. L.; Gust, D. Chem. Mater. 2007, 20, 135.

(5) Qu, S.; Wu, W.; Hua, J.; Kong, C.; Long, Y.; Tian, H. J. Phys. Chem. C 2010, $114,1343$.

(6) Frisch, M. J. e. a. Gaussian 09 Revision A.02, 2009, Gaussian Inc. Wallingford CT. 2009.

(7) Jacquemin, D.; Perpète, E. A.; Ciofini, I.; Adamo, C. Acc. Chem. Res. 2009, 42, 326.

(8) Labat, F.; Ciofini, I.; Hratchian, H. P.; Frisch, M. J.; Raghavachari, K.; Adamo, C. J. Am. Chem. Soc. 2009, 131, 14290. 
(9) Preat, J.; Michaux, C.; Jacquemin, D.; Perpète, E. A. J. Phys. Chem. C 2009, $113,16821$.

(10) Pastore, M.; Fantacci, S.; De Angelis, F. J. Phys. Chem. C 2010, 114, 22742.

(11) Tomasi, J.; Mennucci, B.; Cammi, R. Chem. Rev. 2005, 105, 2999.

(12) Adamo, C.; Barone, V. J. Chem. Phys. 1999, 110, 6158.

(13) Yanai, T.; Tew, D. P.; Handy, N. C. Chem. Phys. Lett. 2004, 393, 51.

(14) Le Bahers, T.; Adamo, C.; Ciofini, I. J. Chem. Theory Comput. 2011, 7, 24982506. 


\section{Graphical abstract for}

\section{Diketopyrrolopyrrole-porphyrin conjugates as broadly absorbing sensitizers for dye-sensitized solar cells}

Julien Warnan, Ludovic Favereau, Frédéric Meslin, Marjorie Severac, Errol Blart, Yann Pellegrin, Denis Jacquemin* and Fabrice Odobel*.

Université de Nantes, CNRS, Chimie et Interdisciplinarité: Synthèse, Analyse, Modélisation (CEISAM), UMR CNRS n ${ }^{\circ}$ 6230, 2, rue de la Houssinière - BP 92208 - 44322 Nantes Cedex 3, France. Tel: +33 (0)2 511254 29. Fax: +33 (0)2 51125402.

E-mail: Fabrice.Odobel@univ-nantes.fr.
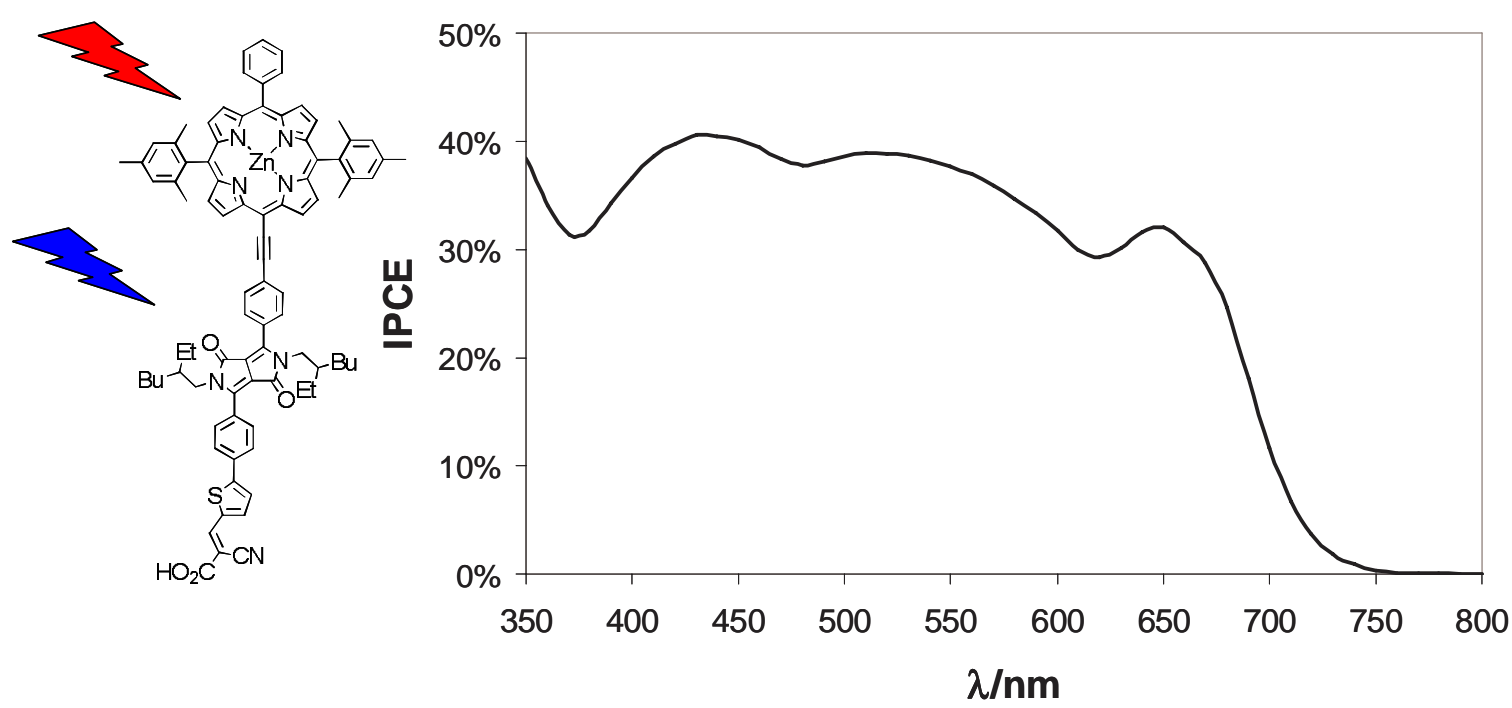